Review

\title{
Quantitative Mass Spectrometry-Based Proteomics for Biomarker Development in Ovarian Cancer
}

\author{
Joohyun Ryu (D) and Stefani N. Thomas* \\ Department of Laboratory Medicine and Pathology, University of Minnesota School of Medicine, \\ 420 Delaware St SE, MMC 609, Minneapolis, MN 55455, USA; jryu@umn.edu \\ * Correspondence: stefanit@umn.edu; Tel.: +1-612-624-1054
}

check for updates

Citation: Ryu, J.; Thomas, S.N. Quantitative Mass SpectrometryBased Proteomics for Biomarker Development in Ovarian Cancer. Molecules 2021, 26, 2674. https:// doi.org/10.3390/molecules26092674

Academic Editors: Francesca Raimondo and Marina Pitto

Received: 23 March 2021

Accepted: 1 May 2021

Published: 3 May 2021

Publisher's Note: MDPI stays neutral with regard to jurisdictional claims in published maps and institutional affiliations.

Copyright: (c) 2021 by the authors. Licensee MDPI, Basel, Switzerland. This article is an open access article distributed under the terms and conditions of the Creative Commons Attribution (CC BY) license (https:// creativecommons.org/licenses/by/ $4.0 /)$.

\begin{abstract}
Ovarian cancer is the most lethal gynecologic malignancy among women. Approximately $70-80 \%$ of patients with advanced ovarian cancer experience relapse within five years and develop platinum-resistance. The short life expectancy of patients with platinum-resistant or platinumrefractory disease underscores the need to develop new and more effective treatment strategies. Early detection is a critical step in mitigating the risk of disease progression from early to an advanced stage disease, and protein biomarkers have an integral role in this process. The best biological diagnostic tool for ovarian cancer will likely be a combination of biomarkers. Targeted proteomics methods, including mass spectrometry-based approaches, have emerged as robust methods that can address the chasm between initial biomarker discovery and the successful verification and validation of these biomarkers enabling their clinical translation due to the robust sensitivity, specificity, and reproducibility of these versatile methods. In this review, we provide background information on the fundamental principles of biomarkers and the need for improved treatment strategies in ovarian cancer. We also provide insight into the ways in which mass spectrometry-based targeted proteomics approaches can provide greatly needed solutions to many of the challenges related to ovarian cancer biomarker development.
\end{abstract}

Keywords: ovarian cancer; biomarker; proteomics; mass spectrometry

\section{Overview of Ovarian Cancer}

Ovarian cancer is a relatively rare cancer compared to other cancers, accounting for approximately 3\% of cancers in women; however, it is the fifth most common cause of cancer death in women [1]. According to the National Cancer Institute's Surveillance, Epidemiology, and End Results (SEER) Program, there were an estimated 21,750 new cases and 13,940 ovarian cancer-related deaths in the United States in 2020, representing 1.2\% of all new cancer cases and $2.3 \%$ of all cancer deaths. Globally, there are approximately 300,000 new cases and roughly 180,000 deaths from ovarian cancer each year. Ovarian cancer is the most lethal gynecologic malignancy cancer among women of advanced age $(>40)$ in developed countries [2,3]. The mortality rate of ovarian cancer is three times higher than that of breast cancer even though the occurrence of ovarian cancer is lower than that of breast cancer $[4,5]$.

Ovarian cancer is staged using the International Federation of Gynecology and Obstetrics (FIGO) system, which is based on surgical results considering the extent of the primary tumor, the presence of cancer in the lymph node, and metastasis to other parts of the body [6,7]. Ovarian cancer has four stages: stage I (early stage) to IV (advanced stage). In stage I, the cancer is limited to the ovaries and has not spread to other regions such as the abdomen, pelvis, or lymph nodes. In stage II, growth of the cancer involves one or both ovaries and fallopian tubes with pelvic extension. In stage III, growth of the cancer involves one or both ovaries or fallopian tubes and the cancer has either spread to the lining of the abdomen or to the lymph nodes in the abdomen. Stage IV is the most 
advanced stage of ovarian cancer, in which the cancer has metastasized to distant areas or organs in the body [8].

Ovarian cancer treatment plans and prognosis vary according to the stage of ovarian cancer. Generally, early detection leads to better outcomes. If the disease is diagnosed and treated in stage I, the 5-year survival rate is $93 \%$ [9]. However, the lack of a proper screening method and the asymptomatic growth of the cancer are the main reasons why ovarian cancer is often not diagnosed until it has reached an advanced stage. More than $75 \%$ of ovarian cancer is diagnosed in stage III or IV. Therefore, ovarian cancer is known as a "silent killer" [5,10,11].

Ovarian cancer is a heterogeneous disease. It encompasses a variety of tumors with various histopathological features and biological behavior [12-14]. Ovarian cancer is classified into more than 30 different types, and most of the types are identified according to the type of cells in which the cancer originated. Malignant ovarian tumors originate most commonly from three cell types: epithelial (most common, accounting for $90 \%$ of all ovarian cancers), germ, and stromal. Each type of cell develops into a different type of cancer: epithelial ovarian carcinoma (EOC), germ cell tumor, and stromal tumor. EOC, which is the most dangerous of all types of ovarian cancers, develops from the cells covering the outer surface of the ovaries and is classified into five subtypes based on tumor cell histology: high-grade serous, low-grade serous, clear cell, endometrioid, and mucinous ovarian cancers $[15,16]$.

EOC is divided into two groups based on distinct biological features and clinical behaviors: type I and type II tumors [13,17]. Low-grade serous ovarian carcinoma (LGSOC), clear cell, low-grade endometrioid, and mucinous carcinomas are classified as type I tumors, which are associated with continuous ovulation, inflammation, and endometriosis [17-19]. Type I tumors grow slowly, cause fewer clinical symptoms, and are frequently diagnosed at an early stage, representing low-grade disease $[14,17]$. Therefore, type I tumors present with an excellent prognosis. However, type I tumors are often resistant to standard chemotherapy [20]. Type I tumors are also characterized by somatic mutations in KRAS, BRAF, PTEN, PIK3CA, CTNNB1, ARID1A, and PPP2R1A genes [21-23]. Mutations in $p 53$ and $B R C A$ genes are rare in type I tumors [17]. Type II EOC tumors are comprised of high-grade serous ovarian carcinoma (HGSOC), high-grade endometrioid carcinoma, undifferentiated carcinoma, and carcinosarcoma. Type II tumors grow fast, are highly aggressive, and present in an advanced stage, representing low survival $[17,19]$. HGSOC, which is the most common subtype among type II tumors, shows relative chromosomal instability compared to type I tumors and is associated with mutations in $p 53(96 \%)$ and $B R C A$ genes $(22 \%)[13,24,25]$.

First-line treatment for ovarian cancer includes cytoreductive surgery followed by chemotherapy combining a platinum compound (cisplatin or carboplatin) and taxane (paclitaxel or docetaxel) [1]. Despite significant advances in first-line treatment in the past few years, the survival rates have improved only slightly. This is due to late diagnosis and a lack of effective second-line treatment for patients with advanced ovarian cancer. Most patients with advanced ovarian cancer such as HGSOC seem to respond well to first-line treatment, but the effects are not typically long-lasting with many of these patients requiring further treatment $[3,16]$. Approximately $70-80 \%$ of patients with advanced ovarian cancer experience relapse within five years and develop platinum-resistance [26,27]. The life expectancy of most patients with platinum-resistance or platinum-refractory disease is less than one year $[3,28]$. Therefore, it is essential to develop new strategies for the treatment of advanced stage ovarian cancer, which is associated with recurrence.

\section{Targeted Therapies for Ovarian Cancer}

Targeted therapies, including poly (ADP-ribose) polymerase (PARP) inhibitors and immunotherapy, have shown promise in improving outcomes in recurrent ovarian cancer $[29,30]$. The use of PARP inhibitors as first-line therapy and maintenance therapy has improved outcomes for women with newly diagnosed advanced ovarian cancer [31]. PARP 
inhibitors target DNA repair pathways including base excision repair, homologous recombination repair and non-homologous end-joining. Therefore, mutations of BRCA genes or other genes involved in homologous recombination repair deficiency, confer sensitivity to PARP inhibitors [16].

Three PARP inhibitors (Olaparib, Rucaparib, and Niraparib) are approved by the U.S. Food and Drug Administration (FDA) as treatment or maintenance therapy for patients with HGSOC who undergo recurrence following platinum-based chemotherapy and harbor germline and/or somatic mutations of $B R C A$ genes [30,32]. Although BRCA1- or BRCA2deficient cancer cells exhibiting defects in homologous recombination (HR deficiency) are hypersensitive to PARP inhibitors [33,34] through the mechanism of synthetic lethality [35], acquired resistance to PARP inhibitors was observed in patients with HR deficient HGSOC. Given the function of $B R C A 1$ or $B R C A 2$ in HR repair [36] and maintaining replication fork stability [37], multiple mechanisms are involved in resistance to PARP inhibitors and cancer cell survival. These include: (1) secondary reversion mutations in restoring wild-type $B R C A 1$ or $B R C A 2$ function in HR repair either by open reading frame (ORF) restoration or somatic reversion of inherited mutations in BRCA1- or BRCA2-deficient cancer cells [38-40]; (2) restoration of HR repair by epigenetic reversion of $B R C A 1$ promoter hypermethylation [37]; (3) hypomorphic alleles such as BRCA1-C61G mutation [41]; (4) stabilization of mutant BRCA1 harboring mutations in its C-terminal (BRCT) domain [42]; (5) restoration of HR repair by loss of PARP1 expression itself [37] and DNA repair proteins such as 53BP1 $[43,44]$ or REV7 [45,46]; and (6) other alternative mechanisms regardless of restoration of HR repair such as increased expression of ABC transporters (e.g., P-glycoprotein (PgP) efflux pump) [47], protection of replication fork stability [48], loss of PARG [49], activation of RAS pathway due to RAS proteins (e.g., KRAS mutant) [50], and activation of the PI3K/AKT pathway [51]. Combating PARP inhibitor resistance can be achieved through combination therapies. Therefore, understanding the detailed mechanisms that cause PARP inhibitor resistance and identifying prognostic biomarkers that predict PARP inhibitor resistance will be needed to overcome PARP inhibitor resistance.

Immunotherapy is a new treatment in advanced ovarian cancer such as HGSOC. This treatment modality uses the body's own immune system to kill cancer cells. In the past few years, immune-checkpoint inhibitors which target immune-checkpoint pathways including cytotoxic T lymphocyte-associated protein 4 (CTLA-4) and PD-1/PD-L1 have been developed in advanced ovarian cancer [16]. Despite encouraging results with immunotherapy in melanoma, non-small cell lung cancer, kidney, and urothelial cancer, immune-check point inhibitors as mono-immunotherapy present modest response rates in ovarian cancer $[29,52,53]$. Further options for the application of immunotherapy in ovarian cancer include a combination of immune-checkpoint inhibitors with chemotherapy or targeted therapy such as anti-angiogenic agents and PARP inhibitors, as well as a combination of immune-checkpoint inhibitors which target different mechanisms in the immune system. Several clinical trials are currently in progress testing these novel treatment approaches [28].

\section{Overview of Ovarian Cancer Biomarkers}

The National Cancer Institute (NCI) defines a biomarker as a biomolecule found in blood, other body fluid, or tissues which is a sign of a normal or abnormal process, or of a condition or disease, which may be used to determine how well the body responds to a treatment for a condition or disease. A biomarker is effectively an indicator of a normal biological process, pathogenic process, or pharmacological response to a therapeutic intervention [54]. Therefore, cancer biomarkers can clarify the development and progression of cancer, predict prognosis and response to therapy, and monitor the risk of recurrence [55].

There are several types of biomarkers for susceptibility/risk assessment, early detection, diagnosis, prognosis, prediction, and monitoring [56]. The intended purpose or utility of a biomarker should be taken into consideration during the development process. Susceptibility/risk assessment biomarkers identify cancer susceptibility, representing a potential risk of developing cancer. These biomarkers do not provide information regarding whether 
a person has cancer at the stated point in time. Biomarkers for early detection, which reflect the presence of cancer, are useful in screening patients to discover cancer at an early stage. Generally, patients who have been informed that they have a high risk based on the expression of a susceptibility/risk assessment biomarker are recommended to undergo frequent screening tests for the early detection of cancer. Diagnostic biomarkers help to identify histopathologic characteristics that correlate with the presence or absence of cancer. Prognostic biomarkers are used to analyze the risk of a patient's clinical outcome in cancer recurrence or cancer progression, regardless of therapy. For example, $B R C A 1 / 2$ mutations are prognostic biomarkers; women who harbor mutations of $B R C A$ genes are expected to have a high risk of developing breast or ovarian cancer in the future [57]. Predictive biomarkers are used to predict a patient's response to a specific treatment or monitor the effectiveness of the treatment, thereby guiding treatment decisions. Monitoring biomarkers can reflect a patient's disease risk or disease status through long-term monitoring of biomarkers. The blood level of CA 125 (Cancer antigen 125), which is among the most widely used ovarian cancer biomarkers, is used to monitor ovarian cancer [58]. More accurate diagnoses as well as more effective and personalized treatment can be achieved by using these types of biomarkers.

In general, cancer is the most common genetic disease that can be attributed to genetic mutations or chromosomal abnormalities. Such genomic instability in cancer cells leads to the alteration of cellular processes, resulting in an uncontrollable state in cancer cell growth $[54,59]$. As a consequence, scientists have endeavored to identify cancer biomarkers using genomics approaches such as next-generation sequencing technologies [60,61]. These large-scale DNA sequencing efforts have accomplished progress in selecting targeted therapy for personalized treatment approaches based on the genomic profile of cancers $[62,63]$. However, genomic profile-based targeted therapy has not been as effective as expected, largely due to the development of drug resistance [64-67]. Genomic alterations are not the only factors that determine the phenotype of cancer cells.

Genes are expressed as multiple proteins with different sequences and activities due to alternatively splicing. Protein expression and function also depend on the transcript levels of their corresponding genes and the translational efficiency. Proteins undergo post-translational modifications (PTMs) to form mature proteins and complexes through protein-protein interaction, which act as important components in cellular processes. Alterations in the expression and activity of proteins can determine the phenotype of the cancer cells as downstream processes of genes [68]. Therefore, quantifying proteomic alterations is as important as identifying genomic changes in the context of targeted therapy.

Proteins have advantages over genes as therapeutic targets in various clinical states: (1) unlike the genome, protein expression is specific to a cell type under specific conditions; (2) environmental influences are more easily reflected in the proteome; (3) the level of protein expression is the result of many upstream processes such as transcription activation, chromatin aberration, transcript degradation and translation efficiency; and (4) proteins are major downstream effectors as well as affecters in various cellular functions $[7,68]$. Several studies have focused on proteomic alterations during carcinogenesis. The most valuable therapeutic targets to study the phenomenon of chemoresistance in advanced ovarian cancer are proteins: kinase inhibitors, PARP inhibitors, and immune-checkpoint inhibitors.

Typically, biomarker discovery begins with identifying targets that exhibit significant changes in a normal biological process, pathogenic process, or pharmacological response. Each target candidate must be validated before proceeding to clinical studies. This includes the development of sensitive and selective assays in order to monitor specific biomarker candidates.

The process of cancer biomarker development includes biomarker discovery, assay development and analytical validation, clinical validation and utility, and clinical implementation [69]. The first step in biomarker development involves the use of preclinical exploratory methods to identify candidate biomarkers. In this discovery step, a large 
number of biomarkers can be detected using omics techniques (genomics, epigenomics, transcriptomics, proteomics, and metabolomics) using human or model organism biofluids or tissues. The second step is assay development to detect or measure biomarker candidates, followed by analytical validation. Analytical validation is a process that is employed to demonstrate the sensitivity, selectivity, precision, accuracy, and reproducibility of the assay $[69,70]$. Typical assay methods that are widely used include antibodybased immunoassays such as western blotting, enzyme-linked immunosorbent assay (ELISA), and immunohistochemistry (IHC). After the analytical validation is established, the biomarker assay must be evaluated to ensure its clinical performance in predicting the clinical outcomes of interest (clinical validation) and improved patient outcomes (clinical utility) $[70,71]$. Clinical validation is the final step in biomarker development, and it entails the use of an analytically validated assay within a clinical trial. Clinical validation is a process to demonstrate the relevance of the biomarker assay in the clinical condition including disease outcome or treatment outcome. Clinical utility is a measure of whether the clinical use of the biomarker assay improves patient outcome, confirms diagnosis, determines appropriate therapy, or identifies individuals who are at risk of developing disease. The clinical utility of biomarkers is important for conducing risk/benefit assessments when used in individual patient management: administering the right therapy for the right patient [72]. An analytically and clinically validated biomarker assay with acceptable performance characteristics is ready to be implemented in clinical treatment. The four key elements associated with implementing biomarker assay in the clinic are as follows: regulatory approval, commercialization, coverage by health insurance companies, and incorporation in clinical practice guidelines [69]. Strict guidelines have been established for the development of clinically useful biomarkers in precision medicine.

Notable advances in omics technologies have facilitated the discovery of numerous new biomarkers at a rapid pace. However, despite great efforts in cancer biomarker development, only a few biomarkers are currently FDA approved, especially in ovarian cancer [73]. This is due to a gap between initial biomarker discovery in the laboratory and translating the findings into using biomarkers in a clinical setting. There is a lack of validation methods ensuring acceptable performance metrics in sensitivity, selectivity, precision, accuracy, high-multiplexing, and high inter-laboratory reproducibility. Traditional antibody-based immunoassays for biomarker verification and validation have major limitations such as low-multiplexing, low inter-laboratory reproducibility, and lack of specific antibodies, especially for mutated or post-translationally modified peptides. Traditional methods are being increasingly substituted by targeted quantitative proteomics methods as a means of verifying and validating biomarker candidates. Targeted quantitative proteomics will be reviewed in Section 5, "Mass spectrometry for biomarker discovery". Targeted quantitative proteomics can address many of the challenges related to biomarker development that have created the chasm between biomarker candidate identification and FDA-approval.

\section{Proteomics in Ovarian Cancer}

Single-marker diagnostics are commonly used in the field of ovarian cancer. The serum biomarker CA125 (Cancer Antigen 125 or MUC16) has long been used as the primary ovarian cancer biomarker for preoperative assessment [74,75]. However, CA125 does not have a role in improving ovarian cancer care. The FDA has not approved CA125 for preoperative use, but rather only for cancer surveillance among women with a diagnosis of ovarian cancer [76]. CA125 has a low sensitivity in predicting ovarian cancer at an early stage $[75,77,78]$. The low sensitivity of CA125 has led to the development of additional serum proteins as candidates for biomarkers that could aid the accuracy of CA125 as an adjunct marker. The combination of CA125 with other biomarkers is an approach that has been pursued in an effort to overcome the limitation of the single use of CA125 [79-81].

In vitro Multivariate Index Assays (IVDMIA) include multiple markers to improve the clinical performance of a diagnostic tool. OVA $1{ }^{\circledR}$ was the first IVDMIA comprised 
of protein biomarkers cleared by the U.S. FDA, and its intended use is to further assess the likelihood of malignancy in women presenting with an ovarian adnexal mass prior to planned surgery $[82,83]$. OVA1 examines five serum proteins (CA125, transferrin, apolipoprotein A-1, transthyretin, and B2-microglobulin). OVA1 is not intended to be used to predict the risk of ovarian cancer in asymptomatic patients without pelvic masses. OVA1 is more sensitive than CA125 alone, but it has a lower specificity. This indicates that OVA1 improves detection in women with ovarian cancer prior to surgery but increases false-positive outcomes. OVA1 detects $94 \%$ of cancer cases, whereas $77 \%$ of cases are detected using CA125 in both pre-menopausal and post-menopausal women [84].

Human epididymis protein 4 (HE4) is a protease inhibitor expressed in malignant epithelial ovarian cells, and it has been identified as the most promising biomarker for ovarian cancer in addition to CA125 [85]. HE4 exhibits the best performance as a single biomarker for distinguishing malignant from benign tumors. In 2008, the FDA approved the use of HE4 in monitoring patients who have a history of ovarian cancer. The detection of HE4 levels in combination with CA125 showed an improvement for the early detection of ovarian cancer [86].

The Risk Of Malignancy Algorithm (ROMA), which measures CA125 and HE4 simultaneously according to a woman's menopausal status, was approved by the FDA in 2011. The ROMA has a higher sensitivity and specificity for the prediction of ovarian cancer in patients with pelvic masses compared to CA125 alone, allowing it to distinguish the risk of a patient with benign (low risk) and malignant (high risk) conditions, which can improve the early detection of ovarian cancer. In the diagnosis of ovarian cancer, ROMA has a sensitivity of $92.3 \%$ with a specificity of $76 \%$ in pre-menopausal women and a sensitivity of $100 \%$ with a specificity of $74.2 \%$ in post-menopausal women [87]. In pre-menopausal women, ROMA values $\geq 1.31$ are highly suggestive of ovarian cancer malignancy, whereas in post-menopausal women, ROMA values $\geq 2.77$ are highly suggestive of ovarian cancer malignancy [18]. However, ROMA is not meant to determine whether a patient requires surgery, and it has not been validated for women previously treated for an ovarian malignancy, women currently being treated with chemotherapy, pregnant women, and women younger than $18[88,89]$.

OVA1 has a relatively low specificity (54\%). The addition of another biomarker to this panel resulted in the next generation of OVA1, OVERA, which was approved by the FDA in 2016. OVERA includes five biomarkers (CA125, HE4, transferrin, apolipoprotein A-1, and follicle-stimulating hormone). Compared to the biomarker panel that comprises OVA1, transthyretin and B2-microglobulin are replaced with HE4 and follicle-stimulating hormone. OVERA is intended to distinguish the risk of patients with malignant tumors from those with benign tumors [90]. OVERA has improved specificity (69\% vs. $54 \%)$ and positive predictive value ( $40 \%$ vs. $31 \%$ ) compared to OVA1 while maintaining high sensitivity (91\%) [91].

The early detection of ovarian cancer is a critical step in mitigating the risk of patients progressing from early stage to advanced stage disease. The best biological diagnostic tool for ovarian cancer seems to be a combination of biomarkers (e.g., IVDMIA). Although the use of multiple biomarkers has less specificity compared to CA125 alone, the benefit of this approach is an increased sensitivity in diagnosing ovarian cancer at an early stage. Thus, when developing methods entailing the use of multiple biomarkers, it is important to improve diagnostic specificity while maintaining high diagnostic sensitivity [92].

Several biomarkers for ovarian cancer have been discovered from various biological sources using methods such as proteomics, lipidomics, and genomics (Table 1). The majority of the protein biomarkers included in this table were identified and characterized using immunoassay-based methods such as enzyme-linked immunoassay (ELISA) and radioimmunoassay (RIA). The National Cancer Institute's Early Detection Research Network (EDRN) website mentions 616 active clinical trials with 232 biomarkers for ovarian cancer (338 Phase 1 trials, 169 Phase 2 trials, 106 Phase 3 trials, 2 Phase 4 trials, and 1 Phase 5 trial) (https://edrn.nci.nih.gov/data-and-resources/biomarkers (accessed on 28 April 2021). 
The readers are encouraged to refer to the resource on the EDRN website for additional details regarding the 232 biomarkers included in Table 1 . The biological functions of most candidate biomarkers have not been fully elucidated, and most initial diagnoses of ovarian cancer are still dependent on CA125 measurement [93].

Table 1. FDA-approved ovarian cancer biomarkers and biomarker candidates.

\begin{tabular}{|c|c|c|c|c|}
\hline Biomarker * & Type & Phase(s) & Clinical Utility & Note $\S$ \\
\hline \multicolumn{5}{|c|}{ FDA-approved biomarkers } \\
\hline CancerSEEK & Gene & 4 & $\begin{array}{l}\text { Detection of } \\
\text { genetic mutations }\end{array}$ & 2019 FDA breakthrough device \\
\hline CA125 & Protein & 4 & Monitoring & Curated for phase 3 in breast \\
\hline HE4 & Protein & 3 & Early detection & \\
\hline OVA1 & Protein panel & 3 & Prediction & \\
\hline Overa & Protein & 5 & Prediction & \\
\hline ROMA & Protein panel & 3 & Prediction & \\
\hline \multicolumn{5}{|c|}{ Biomarker candidates } \\
\hline $\mathrm{APC}$ & Gene & 3,2 & & Under review in breast, lung, and prostate ${ }^{¥}$ \\
\hline CDKN2A (p16) & Gene & 2 & & $\begin{array}{l}\text { Under review for phase } 3 \text { in breast and esophagus; under } \\
\text { review for phase } 1 \text { in lung and prostate }\end{array}$ \\
\hline EGFR & Gene & 3 & & $\begin{array}{c}\text { Curated for phase } 3 \text { in breast; under review for phase } 3 \text { in } \\
\text { lung; under review for phase } 1 \text { in prostate }\end{array}$ \\
\hline NID2 & Gene & 1 & & Curated for phase 1 in head and neck \\
\hline $\mathrm{p} 14 / \mathrm{ARF}$ & Gene & 3,2 & & Under review in prostate and ovary ${ }^{¥}$ \\
\hline SMA4 & Gene & 3 & & \\
\hline $\begin{array}{c}\text { Cramer } 5 \\
\text { marker panel }\end{array}$ & Protein panel & 3 & & HE4, CA15-3, CA125, VTCN1, and CA72-4; Early detection \\
\hline 9 microsatellites & Protein & 2 & & \\
\hline ACKR3 & Protein & 2 & & \\
\hline ACTR3 & Protein & 2 & & \\
\hline ADAM12 & Protein & 2 & & \\
\hline AFP & Protein & 2 & & Certified by FDA in liver \\
\hline AGRN & Protein & 1 & & \\
\hline AKT1 & Protein & 2 & & \\
\hline AMBP & Protein & 1 & & \\
\hline AMY2A & Protein & 3 & & \\
\hline ANXA2 & Protein & 1 & & \\
\hline APCS & Protein & 3 & & \\
\hline APOA1 & Protein & 3 & & Under review for phase 2 in breast and pancreas \\
\hline APOB & Protein & 3,2 & & Under review in breast and ovary $¥$ \\
\hline APOC4 & Protein & 3 & & \\
\hline ARID1A & Protein & 2 & & \\
\hline ATP6AP2 & Protein & 1 & & \\
\hline B2M & Protein & 3 & & \\
\hline BCAM & Protein & 3 & & \\
\hline BLVRB & Protein & 3 & & \\
\hline
\end{tabular}


Table 1. Cont.

\begin{tabular}{|c|c|c|c|c|}
\hline Biomarker * & Type & Phase(s) & Clinical Utility & Note $\S$ \\
\hline BRAF & Protein & 2 & & \\
\hline BRCA1 & Protein & 2 & & Under review for phase 2 in breast \\
\hline BRCA2 & Protein & 2 & & \\
\hline $\mathrm{C} 3$ & Protein & 1 & & \\
\hline CA15-3 & Protein & 3 & & $\begin{array}{l}\text { In ovarian cancer, used with CA125 for monitoring; Curated } \\
\text { for phase } 3 \text { in breast; under review for phase } 2 \text { in lung; under } \\
\text { review for phase } 1 \text { in prostate }\end{array}$ \\
\hline CA19-9 & Protein & 3 & & $\begin{array}{c}\text { In ovarian cancer, used with CA125 for monitoring; Curated } \\
\text { for phase } 3 \text { in breast; under review for phase } 3 \text { in pancreas; } \\
\text { under review for phase } 1 \text { in prostate }\end{array}$ \\
\hline CA72-4 & Protein & 3 & & $\begin{array}{l}\text { In ovarian cancer, used with CA125 for monitoring; Under } \\
\text { review for phase } 2 \text { in breast }\end{array}$ \\
\hline CADM1 & Protein & 3 & & \\
\hline CBLC & Protein & 3,2 & & Under review in lung and ovary $\stackrel{¥}{ }$ \\
\hline CCDC102B & Protein & 2 & & \\
\hline CCL11 & Protein & 3 & & Curated for phase 3 in breast \\
\hline CD248 & Protein & 1 & & \\
\hline CD59 & Protein & 1 & & \\
\hline CDCP1 & Protein & 2 & & \\
\hline CEACAM5 & Protein & 3 & & $\begin{array}{l}\text { Curated for phase } 3 \text { in breast; under review for phase } 2 \text { in } \\
\text { colon, lung, and pancreas; under review for phase } 1 \\
\text { in prostate }\end{array}$ \\
\hline CHI3L1 & Protein & 2 & & \\
\hline CKM & Protein & 1,3 & & Under review in lung and ovary $\stackrel{¥}{ }$ \\
\hline CPA4 & Protein & 1 & & \\
\hline CRIP1 & Protein & 3 & & \\
\hline CRIP2 & Protein & 2 & & \\
\hline CRTAC1 & Protein & 1,3 & & Under review in prostate and ovary $\stackrel{¥}{*}$ \\
\hline CST6 & Protein & 1 & & \\
\hline CTCFL & Protein & 3 & & \\
\hline CTGF & Protein & 1 & & \\
\hline CTNNB1 & Protein & 2 & & Under review in breast, pancreas, and ovary $\underset{ }{¥}$ \\
\hline CXCL8 & Protein & 3 & & $\begin{array}{l}\text { Curated for phase } 2 \text { in bladder; curated for phase } 3 \text { in breast; } \\
\text { under review for phase } 2 \text { in lung; under review for phase } 1 \\
\text { in prostate }\end{array}$ \\
\hline DAG1 & Protein & 1 & & \\
\hline DAPL1 & Protein & 3 & & \\
\hline DEFB1 & Protein & 2 & & \\
\hline DKK3 & Protein & 1 & & \\
\hline DSC2 & Protein & 1,2 & & Under review in prostate and ovary \\
\hline DSG2 & Protein & 1,3 & & Under review in prostate and ovary $\underset{ }{*}$ \\
\hline ECM1 & Protein & 1 & & \\
\hline EFEMP1 & Protein & 1 & & $\begin{array}{l}\text { Under review for phase } 3 \text { in lung; under review for phase } 1 \\
\text { for prostate }\end{array}$ \\
\hline
\end{tabular}


Table 1. Cont.

\begin{tabular}{|c|c|c|c|c|}
\hline Biomarker * & Type & Phase(s) & Clinical Utility & Note $\S$ \\
\hline EFR3A & Protein & 1 & & \\
\hline EGFL6 & Protein & 2 & & \\
\hline EMILIN2 & Protein & 1 & & \\
\hline EPB41L3 & Protein & 2 & & \\
\hline EPCAM & Protein & 1 & & Target for cancer immunotherapy \\
\hline EPSTI1 & Protein & 2 & & \\
\hline ERBB2 & Protein & 3 & & $\begin{array}{c}\text { Curated for phase } 3 \text { in breast; under review for phase } 2 \text { in } \\
\text { colon and lung }\end{array}$ \\
\hline ESM1 & Protein & 3 & & \\
\hline FAM83H & Protein & 2 & & \\
\hline FAS & Protein & 3 & & \\
\hline FBLN1 & Protein & 1 & & \\
\hline FBXW7 & Protein & 2 & & \\
\hline FGFR2 & Protein & 2 & & \\
\hline FGFR4 & Protein & 3 & & \\
\hline FJX1 & Protein & 2 & & \\
\hline FNDC3A & Protein & 1 & & \\
\hline FOLH1B & Protein & 1 & & Under review for phase 1 in prostate \\
\hline FOLR1 & Protein & 1 & & \\
\hline FSH & Protein & 3 & & \\
\hline FSTL1 & Protein & 1 & & \\
\hline FZD10 & Protein & 2 & & \\
\hline GDF15 & Protein & 2 & & \\
\hline GFPT1 & Protein & 3 & & \\
\hline GH1 & Protein & 3 & & Under review for phase 2 in breast \\
\hline GLOD4 & Protein & 1 & & \\
\hline GM2A & Protein & 1 & & \\
\hline GPM6B & Protein & 2 & & Under review for phase 1 in prostate \\
\hline GPR158 & Protein & 3 & & \\
\hline GPR39 & Protein & 1 & & \\
\hline GPR65 & Protein & 2 & & \\
\hline GRN & Protein & 1 & & \\
\hline $\mathrm{H} 2 \mathrm{AFJ}$ & Protein & 3 & & \\
\hline $\mathrm{H} 2 \mathrm{AFV}$ & Protein & 3 & & \\
\hline HAMP & Protein & 3 & & \\
\hline HAPLN1 & Protein & 1 & & Under review for phase 1 in lung \\
\hline HIST1H2AA & Protein & 3 & & \\
\hline HMGB1 & Protein & 3 & & \\
\hline HOXA9 & Protein & 2 & & $\begin{array}{l}\text { Curated for phase } 1 \text { in head and neck; under review for phase } \\
\qquad 1 \text { in prostate }\end{array}$ \\
\hline HSPG2 & Protein & 1 & & \\
\hline HTRA1 & Protein & 1 & & \\
\hline
\end{tabular}


Table 1. Cont.

\begin{tabular}{|c|c|c|c|c|}
\hline Biomarker * & Type & Phase(s) & Clinical Utility & Note $\S$ \\
\hline ICAM1 & Protein & 2 & & $\begin{array}{c}\text { Curated for phase } 3 \text { in breast; under review for phase } 3 \\
\text { in prostate }\end{array}$ \\
\hline IDH1 & Protein & 3 & & \\
\hline IFI27 & Protein & 1 & & \\
\hline IGF2 & Protein & 3 & & \\
\hline IGFBP1 & Protein & 3 & & Under review for phase 2 in breast \\
\hline IGFBP2 & Protein & 3 & & Under review for phase 2 in breast and colon \\
\hline IGFBP3 & Protein & 1,2 & & Under review in pancreas and ovary $\underset{ }{¥}$ \\
\hline IGFBP4 & Protein & 1,3 & & Under review in pancreas and ovary $\underset{ }{¥}$ \\
\hline IGF-II & Protein & 2 & & \\
\hline IL10 & Protein & 3 & & \\
\hline IL2RA & Protein & 3 & & \\
\hline IL6 & Protein & 2 & & Under review for phase 2 in breast \\
\hline IL6R & Protein & 3 & & \\
\hline ITIH4 & Protein & 3 & & \\
\hline $\mathrm{KCP}$ & Protein & 3 & & \\
\hline KLHL14 & Protein & 3 & & \\
\hline KLK6 & Protein & 3 & & Used with CA125 for monitoring \\
\hline KLK8 & Protein & 3 & & Under review for phase 2 in breast and lung \\
\hline KRAS & Protein & $1,3,2$ & & Under review in colon, lung, pancreas, and ovary $\stackrel{¥}{\not}$ \\
\hline KRT19 & Protein & 3 & & Under review in prostate ${ }^{¥}$ \\
\hline KRT8 & Protein & 1 & & \\
\hline LAMA5 & Protein & 3 & & \\
\hline LAMB2 & Protein & 3 & & \\
\hline LAPTM4B & Protein & 1 & & \\
\hline LEP & Protein & 3 & & Under review for phase 2 in breast \\
\hline LGALS3BP & Protein & 1 & & \\
\hline LHB & Protein & 3 & & \\
\hline LPAR3 & Protein & 1 & & \\
\hline LRG1 & Protein & 1,2 & & Under review in breast, pancreas, and ovary $¥$ \\
\hline LRRC47 & Protein & 3 & & \\
\hline LTBP1 & Protein & 1 & & \\
\hline LTBP2 & Protein & 1 & & \\
\hline LY6G6C & Protein & 3 & & \\
\hline LZTS1 & Protein & 1 & & \\
\hline MAPK1 & Protein & 2 & & \\
\hline MIF & Protein & 3 & & Under review for phase 1 in lung \\
\hline MLH1 & Protein & 2 & & Curated for phase 3 in breast \\
\hline MMP2 & Protein & 3 & & \\
\hline MMP3 & Protein & 3 & & $\begin{array}{l}\text { Curated for phase } 3 \text { in breast; under review for phase } 1 \\
\text { in lung }\end{array}$ \\
\hline MMP7 & Protein & 3 & & \\
\hline
\end{tabular}


Table 1. Cont.

\begin{tabular}{|c|c|c|c|c|}
\hline Biomarker * & Type & Phase(s) & Clinical Utility & Note $\S$ \\
\hline MMP9 & Protein & 3 & & $\begin{array}{c}\text { Curated for phase } 2 \text { in bladder; curated for phase } 3 \text { in breast; } \\
\text { under review for phase in lung }\end{array}$ \\
\hline $\mathrm{MPO}$ & Protein & 3,2 & & Under review in breast and ovary $\underset{ }{*}$ \\
\hline MPPED2 & Protein & 2 & & Under review for phase 1 in prostate \\
\hline MPZL2 & Protein & 2 & & Under review for phase 1 in prostate \\
\hline MSH2 & Protein & 2 & & \\
\hline MSLN & Protein & 3 & & \\
\hline MXRA5 & Protein & 1 & & \\
\hline NID1 & Protein & 3 & & \\
\hline NMU & Protein & 3 & & \\
\hline NPC2 & Protein & 1 & & \\
\hline NRAS & Protein & 2 & & \\
\hline NUCB1 & Protein & 1 & & \\
\hline OLFML2B & Protein & 1 & & \\
\hline Osteopontin & Protein & 3 & & $\begin{array}{l}\text { Under review for phase } 3 \text { in breast; under review for phase } 2 \\
\text { in liver; under review for phase } 1 \text { in lung }\end{array}$ \\
\hline OVGP1 & Protein & 1 & & \\
\hline P2RY14 & Protein & 2 & & \\
\hline PCDH17 & Protein & 1 & & \\
\hline PCOLCE & Protein & 1 & & \\
\hline PCSK9 & Protein & 3 & & \\
\hline PEBP1 & Protein & 1 & & \\
\hline PFAS & Protein & 3 & & \\
\hline PGGHG & Protein & 3 & & \\
\hline PI3 & Protein & 1 & & \\
\hline PIK3CA & Protein & 2 & & \\
\hline PIK3R1 & Protein & 2 & & \\
\hline PLEC & Protein & 1 & & \\
\hline PLTP & Protein & 1 & & \\
\hline PLXNB1 & Protein & 3 & & \\
\hline PNP & Protein & 3 & & \\
\hline POLE & Protein & 2 & & \\
\hline POLQ & Protein & 3 & & \\
\hline POSTN & Protein & 3 & & \\
\hline PPBP & Protein & 3 & & \\
\hline PPP2R1A & Protein & 2 & & \\
\hline PRDX6 & Protein & 3 & & \\
\hline PRL & Protein & 3 & & Under review for phase 3 in breast \\
\hline PRMT1 & Protein & 3 & & \\
\hline PROS1 & Protein & 1 & & \\
\hline PSAP & Protein & 1 & & \\
\hline PTEN & Protein & 2 & & \\
\hline
\end{tabular}


Table 1. Cont.

\begin{tabular}{|c|c|c|c|c|}
\hline Biomarker * & Type & Phase(s) & Clinical Utility & Note $\S$ \\
\hline PTH2R & Protein & 3 & & \\
\hline PTK7 & Protein & 3 & & \\
\hline PTPRS & Protein & 3 & & \\
\hline QSOX1 & Protein & 1 & & \\
\hline RMND5A & Protein & 2 & & \\
\hline RNF43 & Protein & 2 & & \\
\hline SCGB2A1 & Protein & 2 & & Under review for phase 1 in prostate \\
\hline SCNN1A & Protein & 1,3 & & Under review in prostate and ovary \\
\hline SDC1 & Protein & 2 & & Curated for phase 2 in bladder \\
\hline SEC23B & Protein & 2 & & \\
\hline SECTM1 & Protein & 1 & & \\
\hline SELENBP1 & Protein & 3 & & \\
\hline SERPINA6 & Protein & 1 & & \\
\hline SERPINE1 & Protein & 3 & & $\begin{array}{l}\text { Curated for phase } 2 \text { in bladder; under review for phase } 2 \\
\text { in breast }\end{array}$ \\
\hline SLAMF8 & Protein & 2 & & \\
\hline SLC11A1 & Protein & 1 & & \\
\hline SLC30A6 & Protein & 2 & & \\
\hline SLPI & Protein & 3 & & Under review for phase 1 in lung and prostate \\
\hline SMRP & Protein & 2 & & Under review for phase 4 in lung \\
\hline SOD3 & Protein & 3 & & \\
\hline SPINT2 & Protein & 1 & & \\
\hline SPON1 & Protein & 3 & & \\
\hline SPON2 & Protein & 3 & & Under review for phase 2 in colon \\
\hline SPP2 & Protein & 3 & & \\
\hline ST13 & Protein & 3 & & \\
\hline ST14 & Protein & 2 & & \\
\hline TAGLN2 & Protein & 1 & & \\
\hline TF & Protein & 3 & & Under review for phase 1 in prostate \\
\hline TNF & Protein & 3,2 & & Under review in breast, lung, and ovary ${ }^{¥}$ \\
\hline TNFAIP1 & Protein & 2 & & \\
\hline TNFAIP6 & Protein & 2 & & \\
\hline TNFRSF1A & Protein & 3 & & \\
\hline TNFRSF1B & Protein & 3 & & \\
\hline TNFRSF21 & Protein & 3 & & \\
\hline TNFRSF6B & Protein & 3,2 & & Under review in colon and ovary $¥$ \\
\hline TP53 & Protein & 1,2 & & $\begin{array}{l}\text { Under review in breast, colon, lung, pancreas, prostate, } \\
\text { and ovary }\end{array}$ \\
\hline Transthyretin & Protein & 3 & & \\
\hline TSHB & Protein & 3 & & \\
\hline TSSK4 & Protein & 3 & & \\
\hline VCAM1 & Protein & 3 & & Curated for phase 3 in breast \\
\hline
\end{tabular}


Table 1. Cont.

\begin{tabular}{ccccc}
\hline Biomarker & Type & Phase(s) & Clinical Utility & Note \\
\hline VCAN & Protein & 3 & \\
\hline VTA1 & Protein & 2 & \\
\hline VTCN1 & Protein & 3 & Used with CA125 for monitoring \\
\hline VWF & Protein & 1 & \\
\hline WNT10A & Protein & 3 & \\
\hline WWC1 & Protein & 1 & \\
\hline
\end{tabular}

* The information related to the biomarkers included in this table was obtained from the National Cancer Institute's Early Detection Research Network (EDRN) website (https:/ / edrn.nci.nih.gov/data-and-resources/biomarkers (accessed on April 28, 2021). \$ Additional information for each biomarker. ${ }^{¥}$ No information for phase(s) according to organs.

\section{Mass Spectrometry for Biomarker Development}

Over the last decade, mass spectrometry-based proteomics has become a promising technology to reveal the quantitative state of the human proteome. This is due in large part to dramatic advances in mass spectrometry instrumentation, peptide/protein identification and quantification algorithms, and bioinformatics computational data analysis. Quantitative proteomics advances in biomedical research provide insights into the dynamic proteome state associated with different biological conditions such as environmental stress, genetic mutations, drug treatment, and diseases [3,94-99]. The characterization of the dynamic proteome states can reveal pathogenic mechanisms as well as lead to significant advances in biomarker development by identifying distinct proteins for biomarkers and therapeutic targets.

Mass spectrometry-based proteomics can be categorized into top-down or bottom-up approaches. In top-down proteomics, intact proteins are measured, whereas in bottom-up proteomics, peptides are measured as surrogates for the proteins of interest. Most advanced quantitative proteomics methods for biomarker development are performed using bottomup proteomics. Two types of quantitative approaches are employed in biomarker studies: untargeted quantitative proteomics for biomarker discovery and targeted quantitative proteomics for biomarker verification and validation. In the workflow for biomarker development, first, a large number of biomarker candidates are identified from a few sample cohorts using untargeted global quantitative proteomics in the discovery stage. Then, a small number of biomarker candidates are further evaluated for reproducibility in a large number of sample cohorts during the verification stage. Finally, the most promising biomarker candidates are validated to assess their sensitivity, specificity, and clinical utility in a much larger number of sample cohorts.

Untargeted quantitative proteomics approaches that are designed to yield an indepth unbiased quantitation of the global proteome include label-free and stable isotope labeling techniques using a data dependent acquisition (DDA) mode. Stable isotope labeling uses the mass increase caused by the mass tags with incorporated stable isotopes to quantify peptides at the MS1 full scan (precursor ion) level or peptide fragments at the MS2 (production ion) scan level. There are several strategies to label peptides or proteins with stable isotopes: chemical labeling such as Isobaric Tags for Relative and Absolute Quantitation (iTRAQ) [97,100-102] and Tandem Mass Tags (TMT) [103-106], and metabolic labeling strategies such as Stable Isotope Labeling by Amino acids in Cell culture (SILAC) [107-110]. Data independent acquisition (DIA) methods can also be used for quantitative studies (Figure 1).

Label-free quantitation uses mass spectrometric signal intensity or peptide spectral counts for peptide and protein quantitation. Label-free quantitation can be performed with DDA and DIA. In DIA, MS2 scans are acquired from all of the detectable peptide ions within the indicated MS1 full scan detection window, as opposed to selecting a fixed number of precursor ions from the most abundant peptides in the MS1 full scan to acquire MS2 
scans when using DDA [111]. Quantification is most commonly conducted based on the summation of the intensities of peptide-specific fragment ions in MS2 scans, the identities of which are obtained from ion (spectral) libraries generated using DDA. DIA technologies are mass spectrometer platform-dependent. For example, the representative DIA technologies are BoxCar [112], SWATH [113,114], diaPASEF [115] and MSE and SONAR [116-118], which are scan modes for Orbitrap (Thermo, Waltham, MA, USA), TripleToF (Sciex, Framingham, MA, USA), Q-Tof (Bruker, Billerica, MA, USA) and Q-ToF (Waters, Milford, MA, USA) mass spectrometers, respectively.

A.

DDA
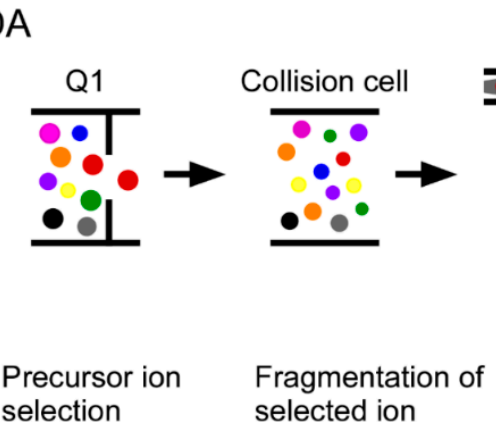

Orbitrap

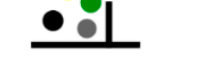

elected ion

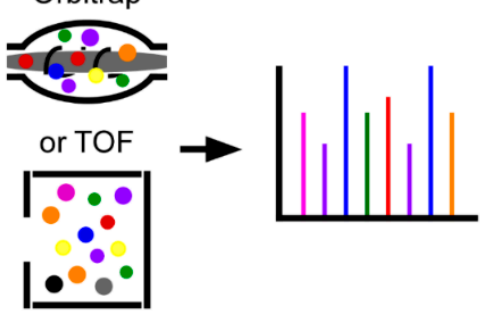

Precursor ion selection

Detection of all fragmented ions

B.

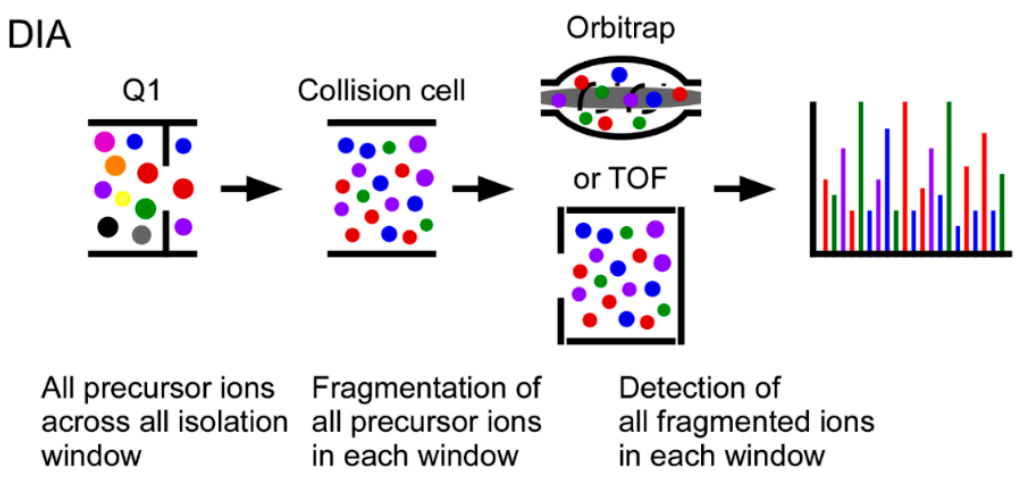

Figure 1. Principles of data-dependent acquisition (DDA) and data-independent acquisition (DIA) in untargeted quantitative proteomics. (A) In DDA, precursor ions are stochastically selected on the basis of their signal intensity in Q1 followed by fragmentation of the selected precursor ions in a collision cell. All fragmented ions are separated and detected by a mass analyzer such as an Orbitrap or time-of-flight (TOF) analyzer. (B) In DIA, all MS1 precursor ions within pre-defined mass windows are selected in Q1 followed by fragmentation of all precursor ions from each window in a collision cell. The resultant MS2 spectra are comprised of fragment ions from all of the precursor ions in the selected Q1 window.

In biomarker discovery, global proteome analysis using untargeted quantitative proteomics presents promising relative quantitation data for large numbers of biomarker candidates. However, a critical limitation for this approach is the low reproducibility and higher missing values for low abundance peptides/proteins due to the stochastic nature of abundance-based precursor ion selection in the DDA mode, which cannot guarantee that the same peptides will be consistently detected in all analyses. Data imputation or DIA can be used to partially overcome the challenges associated with missing values. This limitation indicates that untargeted global quantitative proteomics approaches are not suitable for the verification and validation of biomarker candidates. 
To assess the clinical utility of statistically significant biomarker candidates, it is important to analyze specific peptides/proteins using methods with high sensitivity and reproducibility in a large number of sample cohorts. In this respect, targeted quantitative proteomics, Nature Method's choice for method of the year in 2012, is a powerful technology for biomarker candidate verification and validation due to its capability to consistently identify and quantify peptides/proteins with higher sensitivity, specificity, reproducibility at a higher sample throughput compared to DDA-based untargeted global quantitative proteomics [119].

Targeted quantitative proteomics methods include multiple reaction monitoring (MRM) and parallel reaction monitoring (PRM) (Figure 2) [120]. DIA is considered a targeted data extraction quantitative method, as opposed to a targeted data acquisition method. In general, missing values are less of a challenge with DIA methods compared to DDA $[119,121]$. The relatively lower sensitivity, specificity, and reproducibility of DIA compared to MRM and PRM indicate that DIA is still more suitable for biomarker discovery instead of biomarker verification and validation, although DIA has advantages related to its analyte multiplexing capability and relative ease of assay development compared to MRM and PRM [122,123]. Therefore, the most widely used targeted methods are MRM and PRM, which can facilitate quantitation accuracy and reproducibility $[124,125]$. To achieve the desired accuracy and reproducibility, various parameters need to be optimized including precursor and product ion selection, collision energy and transmission settings for maximum sensitivity, and determination of liquid chromatography (LC) retention time $[119,126]$. In targeted quantitative proteomics methods, these are key concepts to obtain consistent peptide quantification metrics for proteins of interest in a large number of sample cohorts as well as inter-laboratory experiments.

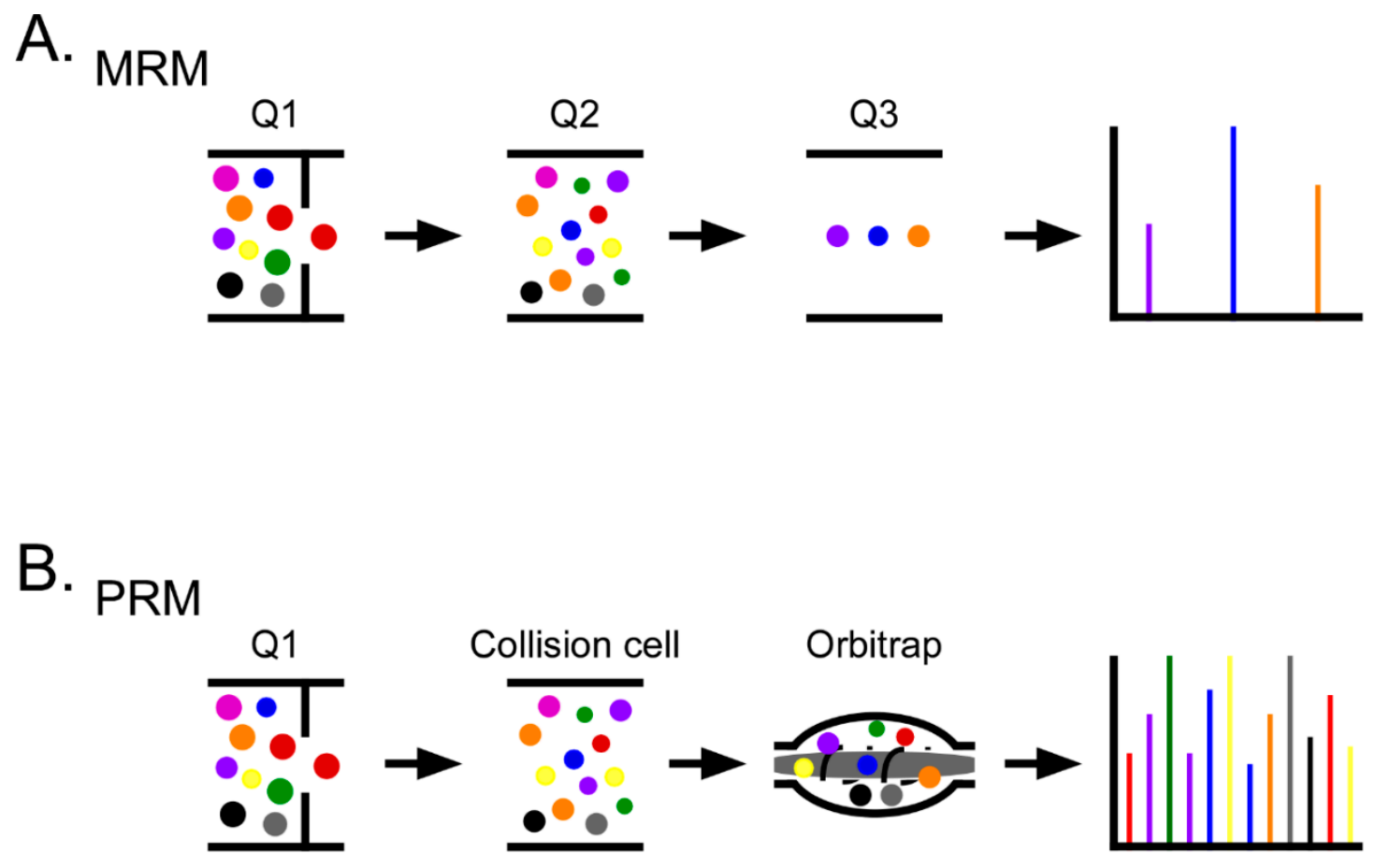

Figure 2. Schematic overview of targeted quantitative proteomics methods. (A) In multiple reaction monitoring (MRM), the precursor ion of a pre-defined specific peptide is selected and fragmented in Q1 and Q2, respectively. Pre-defined fragmented ions are selected and detected in Q3. (B) Unlike MRM, parallel reaction monitoring (PRM) can detect all fragmented ions generated from precursor ions in parallel using a high resolution accurate mass (HRAM) mass analyzer such as an Orbitrap.

MRM is a traditional targeted quantitative proteomics approach that is performed using triple quadrupole (QqQ) or quadrupole linear ion trap (QTRAP) instruments [127]. 
MRM uses the unique features of a QqQ or QTRAP instrument to detect the combinations of precursor and product ions that are termed MRM transitions (Q1/Q3 MRM ion pairs). The targeted specific precursor ions for peptides of interest are selected in the first quadrupole (Q1), and then transmitted into the collision cell (q2) for fragmentation. Finally, specific product ions from the targeted precursor ions are selected in the third quadrupole (Q3) for detection. Often, Q3 is a low-resolution mass analyzer, which cannot transmit ions with isolation widths $<0.7-1.0 \mathrm{Da}$ without losing sensitivity [119].

PRM is a newer targeted acquisition method that is performed with high resolution accurate mass (HRAM) mass analyzers such as Orbitraps (Thermo Scientific, Waltham, MA, USA). Compared to the QqQ-dependent MRM methods described above, in PRM methods, Q3 is substituted with an HRAM mass analyzer, which allows the parallel detection of all product ions from targeted precursor ions instead of selecting a limited number of product ions (typically three transitions) as is the case in MRM methods [128]. Therefore, PRM has several advantages compared to MRM. PRM provides highly specific spectra for all product ions from selected precursor ions, thereby permitting high confidence targeted peptide identification $[128,129]$. Since PRM uses several transitions to identify and quantify peptides, the predetermination of transitions and collision energy as required for MRM is not necessary for PRM, thus reducing the time required for method development. Compared to MRM, PRM provides significant improvement in signal-to-noise with high sensitivity. Interference from background ions is minimized when data are acquired using an HRAM mass analyzer [130]. These advantages of PRM suggest that PRM will be useful to characterize targeted peptides with post-translational modifications (PTMs) [125], which is difficult when using MRM. However, PRM has a relatively longer scan time for each targeted precursor ion compared to MRM, resulting in decreased efficiency when targeting multiple peptides simultaneously.

One of the most significant challenges in biomarker verification and validation using targeted quantitative proteomics approaches is the lack of sufficient sensitivity for detecting extremely low abundance proteins in body fluids. For example, the top 20 most abundant proteins in blood plasma/serum constitute approximately $99 \%$ of the total protein mass, while thousands of other proteins, including potential biomarker candidates, comprise $1 \%$ of the total protein mass and are present at concentrations as low as $\mathrm{ng} / \mathrm{mL}$ or sub-ng/mL levels. Therefore, several methods have been developed to improve the detection capabilities in targeted quantitative proteomics approaches. These methods include immunoaffinity enrichment to enrich low abundance proteins or specific targeted proteins, immunoaffinity depletion to deplete high abundance interfering components, and fractionation to reduce the sample complexity [131]. These methods enable the improved detection of low abundance proteins by reducing the sample complexity.

Many regulatory agencies adopt the standards and guidelines published by the Clinical and Laboratory Standards Institute (CLSI) when setting regulatory guidelines for clinical laboratories. A forthcoming CLSI guidance document, "C64: Quantitative Measurement of Proteins and Peptides by Mass Spectrometry", will provide a framework for developing clinical protein and peptide assays from conception to validation. To improve the translation of assays to clinical use, this guidance document focuses on the development of targeted mass spectrometry-based protein assays linked to clinically relevant analytical validation. The C64 guidance document provides broad recommendations for appropriately developing and validating quantitative protein and peptide assays for clinical applications while focusing on practical workflows and experimental strategies for developing and validating quantitative assays for soluble proteins and peptides in biofluids.

As mentioned in Section 3, "Overview of ovarian cancer biomarkers", targeted quantitative proteomics approaches can bridge the chasm between candidate biomarker discovery and clinical utility. In biomedical research for personalized medicine, targeted quantitative proteomics methods can be used to develop biomarkers that are identified from untargeted global proteomics methods, and these targeted methods have potential use in screening individuals or patient cohorts according to disease risk or disease status [132]. This person- 
alized approach can facilitate the early and highly sensitive detection of disease through long-term biomarker monitoring. In addition, targeted quantitative proteomics methods can be applied in systems biology research. Targeted quantitative proteomics methods can provide accurate quantitation of key proteins or protein complexes to provide insight into the dynamics of signaling pathways to understand the molecular mechanisms of signal transduction [133-135].

\section{Future Perspectives}

Targeted quantitative proteomics has become essential for the quantification of hundreds of biomarker candidates across several samples with high sensitivity, specificity, reproducibility, consistency, and accuracy [127,136-138]. Although antibody-based methods such as ELISA provide high sensitivity to quantify proteins, targeted quantitative proteomics can be used to overcome some of the limitations of these antibody-based methods including low specificity and selectivity. Targeted quantitative proteomics methods have been successfully used to verify and validate biomarker candidates in different types of cancer including ovarian [139-142], prostate [143,144], lung [145,146], colorectal [147], breast [148], liver [149-152], and pancreatic [153,154].

Despite great advances in targeted quantitative proteomics to facilitate the consistent identification and quantitation of peptides and proteins, the throughput of these methods is typically limited at $\sim 50-100$ proteins per single analysis. Compared to untargeted quantitative proteomics using DDA, targeted quantitative proteomics has a relatively low sample multiplexing ability. Achieving high-throughput measurements for hundreds of biomarker candidates will require advanced MS instrumentation that can provide throughput on the scale of DDA with the established advantages of targeted quantitative proteomics.

\section{Conclusions}

Untargeted and targeted quantitative proteomics have significantly improved biomarker discovery and validation efforts, respectively. Targeted quantitative proteomics approaches can bridge the gap between the discovery and validation phases in biomarker development in not only ovarian cancer, but also several other disease states for which there is an urgent need for biomarkers to enable early disease detection.

Author Contributions: Conceptualization, S.N.T. and J.R.; Writing-Original draft preparation, J.R. and S.N.T.; Writing-Review \& Editing, S.N.T.; Supervision, S.N.T.; Funding Acquisition, S.N.T. All authors have read and agreed to the published version of the manuscript.

Funding: SNT acknowledges funding from the National Institutes of Health's National Center for Advancing Translational Sciences, grant UL1TR002494. The content is solely the responsibility of the authors and does not necessarily represent the official views of the National Institutes of Health's National Center for Advancing Translational Sciences. SNT also acknowledges startup funds provided by the University of Minnesota Department of Laboratory Medicine and Pathology.

Institutional Review Board Statement: Not applicable.

Informed Consent Statement: Not applicable.

Data Availability Statement: Not applicable.

Conflicts of Interest: The authors declare no conflict of interest.

\section{References}

1. Roett, M.A.; Evans, P. Ovarian Cancer: An Overview. Am. Fam. Physician 2009, 80, 609-616. [PubMed]

2. Stewart, C.; Ralyea, C.; Lockwood, S. Ovarian Cancer: An Integrated Review. Semin. Oncol. Nurs. 2019, 35, 151-156. [CrossRef]

3. Elzek, M.A.; Rodland, K.D. Proteomics of ovarian cancer: Functional insights and clinical applications. Cancer Metastasis Rev. 2015, 34, 83-96. [CrossRef] [PubMed]

4. Thomson, C.; Caan, B. Breast and Ovarian Cancer. In Optimizing Women's Health through Nutrition; Apple Academic Press: Palm Bay, FL, USA, 2007; Volume 60, pp. 229-263. 
5. Momenimovahed, Z.; Tiznobaik, A.; Taheri, S.; Salehiniya, H. Ovarian cancer in the world: Epidemiology and risk factors. Int. J. Womens Health 2019, 11, 287-299. [CrossRef] [PubMed]

6. Schumer, S.T.; Cannistra, S.A. Granulosa Cell Tumor of the Ovary. J. Clin. Oncol. 2003, 21, 1180-1189. [CrossRef] [PubMed]

7. Pokhriyal, R.; Hariprasad, R.; Kumar, L.; Hariprasad, G. Chemotherapy Resistance in Advanced Ovarian Cancer Patients. Biomark. Cancer 2019, 11, 1179299-1986081. [CrossRef]

8. Prat, J. FIGO's staging classification for cancer of the ovary, fallopian tube, and peritoneum: Abridged republication. J. Gynecol. Oncol. 2015, 26, 87-89. [CrossRef]

9. Torre, L.A.; Trabert, B.; DeSantis, C.E.; Mph, K.D.M.; Samimi, G.; Runowicz, C.D.; Gaudet, M.M.; Jemal, A.; Siegel, R.L. Ovarian cancer statistics, 2018. CA Cancer J. Clin. 2018, 68, 284-296. [CrossRef]

10. Jayson, G.C.; Kohn, E.C.; Kitchener, H.C.; Ledermann, J.A. Ovarian cancer. Lancet 2014, 384, 1376-1388. [CrossRef]

11. Chien, J.; Poole, E.M. Ovarian Cancer Prevention, Screening, and Early Detection. Int. J. Gynecol. Cancer 2017, 27, S20-S22. [CrossRef] [PubMed]

12. Wentzensen, N.; Poole, E.M.; Trabert, B.; White, E.; Arslan, A.A.; Patel, A.V.; Setiawan, V.W.; Visvanathan, K.; Weiderpass, E.; Adami, H.-O.; et al. Ovarian Cancer Risk Factors by Histologic Subtype: An Analysis From the Ovarian Cancer Cohort Consortium. J. Clin. Oncol. 2016, 34, 2888-2898. [CrossRef] [PubMed]

13. Kurman, R.J.; Shih, I.M. The dualistic model of ovarian carcinogenesis revisited, revised, and expanded. Am. J. Pathol. 2016, 186, 733-747. [CrossRef]

14. Smolle, E.; Taucher, V.; Pichler, M.; Petru, E.; Lax, S.; Haybaeck, J. Targeting Signaling Pathways in Epithelial Ovarian Cancer. Int. J. Mol. Sci. 2013, 14, 9536-9555. [CrossRef]

15. Köbel, M.; Kalloger, S.E.; Boyd, N.; McKinney, S.; Mehl, E.; Palmer, C.; Leung, S.; Bowen, N.J.; Ionescu, D.N.; Rajput, A.; et al. Ovarian Carcinoma Subtypes Are Different Diseases: Implications for Biomarker Studies. PLoS Med. 2008, 5, e232. [CrossRef]

16. Lheureux, S.; Msc, M.B.; Oza, A.M. Epithelial ovarian cancer: Evolution of management in the era of precision medicine. CA Cancer J. Clin. 2019, 69, 280-304. [CrossRef]

17. Kurman, R.J.; Shih, I.-M. Molecular pathogenesis and extraovarian origin of epithelial ovarian cancer-Shifting the paradigm. Hum. Pathol. 2011, 42, 918-931. [CrossRef] [PubMed]

18. De Carvalho, V.P.; Grassi, M.L.; Palma, C.D.S.; Carrara, H.H.A.; Faça, V.M.; Dos Reis, F.J.C.; Poersch, A. The contribution and perspectives of proteomics to uncover ovarian cancer tumor markers. Transl. Res. 2019, 206, 71-90. [CrossRef]

19. Kurman, R.J.; Shih, I.-M. The Origin and Pathogenesis of Epithelial Ovarian Cancer: A Proposed Unifying Theory. Am. J. Surg. Pathol. 2010, 34, 433-443. [CrossRef] [PubMed]

20. Romero, I.; Bast, R.C. Minireview: Human Ovarian Cancer: Biology, Current Management, and Paths to Personalizing Therapy. Endocrinology 2012, 153, 1593-1602. [CrossRef] [PubMed]

21. Wiegand, K.C.; Shah, S.P.; Al-Agha, O.M.; Zhao, Y.; Al, E. ARID1A Mutations in Endometriosis-Associated Ovarian Carcinomas. N. Engl. J. Med. 2011, 363, 1532-1543. [CrossRef]

22. Jones, S.; Wang, T.-L.; Shih, L.-M.; Mao, T.-L.; Nakayama, K.; Roden, R.; Glas, R.; Slamon, D.; Diaz, L.A., Jr.; Vogelstein, B.; et al. Frequent Mutations of Chromatin remodeling gene ARID1A in ovarian clear cell carcinoma. Science 2010, 330, $228-231$. [CrossRef] [PubMed]

23. Shih, I.-M.; Kurman, R.J. Ovarian Tumorigenesis. Am. J. Pathol. 2004, 164, 1511-1518. [CrossRef]

24. Ahmed, A.A.; Etemadmoghadam, D.; Temple, J.; Lynch, A.G.; Riad, M.; Sharma, R.; Stewart, C.; Fereday, S.; Caldas, C.; DeFazio, A.; et al. Driver mutations in TP53 are ubiquitous in high grade serous carcinoma of the ovary. J. Pathol. 2010, 221, 49-56. [CrossRef] [PubMed]

25. Landen, C.N., Jr.; Birrer, M.J.; Sood, A.K. Early Events in the Pathogenesis of Epithelial Ovarian Cancer. J. Clin. Oncol. 2008, 26, 995-1005. [CrossRef] [PubMed]

26. Wilson, M.K.; Pujade-Lauraine, E.; Aoki, D.; Mirza, M.R.; Lorusso, D.; Oza, A.M.; du Bois, A.; Vergote, I.; Reuss, A.; Bacon, M.; et al. Fifth Ovarian Cancer Consensus Conference of the Gynecologic Cancer InterGroup: Recurrent disease. Ann. Oncol. 2017, 28, 727-732. [CrossRef]

27. Bookman, M.; Okamoto, A.; Stuart, G.; Yanaihara, N.; Aoki, D.; Bacon, M.; Fujiwara, K.; González-Martín, A.; Harter, P.; Kim, J.; et al. Harmonising clinical trials within the Gynecologic Cancer InterGroup: Consensus and unmet needs from the Fifth Ovarian Cancer Consensus Conference. Ann. Oncol. 2017, 28, viii30-viii35. [CrossRef]

28. Palaia, I.; Tomao, F.; Sassu, C.M.; Musacchio, L.; Panici, P.B. Immunotherapy For Ovarian Cancer: Recent Advances And Combination Therapeutic Approaches. Onco Targets Ther. 2020, 13, 6109-6129. [CrossRef]

29. Pujade-Lauraine, E. New treatments in ovarian cancer. Ann. Oncol. 2017, 28, viii57-viii60. [CrossRef]

30. Wang, Q.; Peng, H.; Qi, X.; Wu, M.; Zhao, X. Targeted therapies in gynecological cancers: A comprehensive review of clinical evidence. Signal Transduct. Target. Ther. 2020, 5, 1-34. [CrossRef]

31. Callens, C.; Vaur, D.; Soubeyran, I.; Rouleau, E.; Just, P.-A.; Guillerm, E.; Golmard, L.; Goardon, N.; Sevenet, N.; Cabaret, O.; et al. Concordance Between Tumor and Germline BRCA Status in High-Grade Ovarian Carcinoma Patients in the Phase III PAOLA-1/ENGOT-ov25 Trial. J. Natl. Cancer Inst. 2020. [CrossRef]

32. Pignata, S.; Pisano, C.; Di Napoli, M.; Cecere, S.C.; Tambaro, R.; Attademo, L. Treatment of recurrent epithelial ovarian cancer. Cancer 2019, 125, 4609-4615. [CrossRef] [PubMed] 
33. Farmer, H.; McCabe, N.; Lord, C.J.; Tutt, A.N.J.; Johnson, D.A.; Richardson, T.B.; Santarosa, M.; Dillon, K.J.; Hickson, I.D.; Knights, C.; et al. Targeting the DNA repair defect in BRCA mutant cells as a therapeutic strategy. Nature 2005, 434, 917-921. [CrossRef] [PubMed]

34. Bryant, H.E.; Schultz, N.; Thomas, H.D.; Parker, K.M.; Flower, D.; Lopez, E.; Kyle, S.; Meuth, M.; Curtin, N.J.; Helleday, T. Specific killing of BRCA2-deficient tumours with inhibitors of poly(ADP-ribose) polymerase. Nature 2005, 434, 913-917. [CrossRef] [PubMed]

35. Lord, C.J.; Ashworth, A. PARP inhibitors: Synthetic lethality in the clinic. Science 2017, 355, 1152-1158. [CrossRef] [PubMed]

36. Ledermann, J.A.; Drew, Y.; Kristeleit, R.S. Homologous recombination deficiency and ovarian cancer. Eur. J. Cancer 2016, 60, 49-58. [CrossRef]

37. D'Andrea, A.D. Mechanisms of PARP inhibitor sensitivity and resistance. DNA Repair 2018, 71, 172-176. [CrossRef]

38. Sakai, W.; Swisher, E.M.; Jacquemont, C.; Chandramohan, K.V.; Couch, F.J.; Langdon, S.P.; Wurz, K.; Higgins, J.; Villegas, E.; Taniguchi, T. Functional Restoration of BRCA2 Protein by Secondary BRCA2 Mutations in BRCA2-Mutated Ovarian Carcinoma. Cancer Res. 2009, 69, 6381-6386. [CrossRef]

39. Barber, L.J.; Sandhu, S.; Chen, L.; Campbell, J.; Kozarewa, I.; Fenwick, K.; Assiotis, I.; Rodrigues, D.N.; Reis-Filho, J.S.; Moreno, V.; et al. Secondary mutations in BRCA2 associated with clinical resistance to a PARP inhibitor. J. Pathol. 2013, 229, 422-429. [CrossRef]

40. Quigley, D.; Alumkal, J.J.; Wyatt, A.W.; Kothari, V.; Foye, A.; Lloyd, P.; Aggarwal, R.; Kim, W.; Lu, E.; Schwartzman, J.; et al. Analysis of Circulating Cell-Free DNA Identifies Multiclonal Heterogeneity of BRCA2 Reversion Mutations Associated with Resistance to PARP Inhibitors. Cancer Discov. 2017, 7, 999-1005. [CrossRef]

41. Drost, R.; Bouwman, P.; Rottenberg, S.; Boon, U.; Schut, E.; Klarenbeek, S.; Klijn, C.; van der Heijden, I.; van der Gulden, H.; Wientjens, E.; et al. BRCA1 RING Function Is Essential for Tumor Suppression but Dispensable for Therapy Resistance. Cancer Cell 2011, 20, 797-809. [CrossRef]

42. Johnson, N.; Johnson, S.F.; Yao, W.; Li, Y.-C.; Choi, Y.-E.; Bernhardy, A.J.; Wang, Y.; Capelletti, M.; Sarosiek, K.A.; Moreau, L.A.; et al. Stabilization of mutant BRCA1 protein confers PARP inhibitor and platinum resistance. Proc. Natl. Acad. Sci. USA 2013, 110, 17041-17046. [CrossRef] [PubMed]

43. Bouwman, P.; Aly, A.; Escandell, J.M.; Pieterse, M.; Bartkova, J.; Van Der Gulden, H.; Hiddingh, S.; Thanasoula, M.; Kulkarni, A.; Yang, Q.; et al. 53BP1 loss rescues BRCA1 deficiency and is associated with triple-negative and BRCA-mutated breast cancers. Nat. Struct. Mol. Biol. 2010, 17, 688-695. [CrossRef]

44. Jaspers, J.E.; Kersbergen, A.; Boon, U.; Sol, W.; Van Deemter, L.; Zander, S.A.; Drost, R.; Wientjens, E.; Ji, J.; Aly, A.; et al. Loss of 53BP1 Causes PARP Inhibitor Resistance in Brca1-Mutated Mouse Mammary Tumors. Cancer Discov. 2013, 3, 68-81. [CrossRef] [PubMed]

45. Boersma, V.; Moatti, N.; Segura-Bayona, S.; Peuscher, M.H.; van der Torre, J.; Wevers, B.A.; Orthwein, A.; Durocher, D.; Jacobs, J.J.L. MAD2L2 controls DNA repair at telomeres and DNA breaks by inhibiting $5^{\prime}$ end resection. Nature 2015, 521, 537-540. [CrossRef]

46. Xu, G.; Chapman, J.R.; Brandsma, I.; Yuan, J.; Mistrik, M.; Bouwman, P.; Bartkova, J.; Gogola, E.; Warmerdam, D.; Barazas, M.; et al. REV7 counteracts DNA double-strand break resection and affects PARP inhibition. Nature 2015, 521, 541-544. [CrossRef]

47. Vaidyanathan, A.; Sawers, L.; Gannon, A.-L.; Chakravarty, P.; Scott, A.L.; Bray, S.E.; Ferguson, M.J.; Smith, G. ABCB1 (MDR1) induction defines a common resistance mechanism in paclitaxel- and olaparib-resistant ovarian cancer cells. Br. J. Cancer 2016, 115, 431-441. [CrossRef] [PubMed]

48. Chaudhuri, A.R.; Callen, E.; Ding, X.; Gogola, E.; Duarte, A.A.; Lee, J.-E.; Wong, N.; Lafarga, V.; Calvo, J.A.; Panzarino, N.J.; et al. Replication fork stability confers chemoresistance in BRCA-deficient cells. Nature 2016, 535, 382-387. [CrossRef]

49. Gogola, E.; Duarte, A.A.; de Ruiter, J.R.; Wiegant, W.W.; Schmid, J.A.; de Bruijn, R.; James, D.I.; Llobet, S.G.; Vis, D.J.; Annunziato, S.; et al. Selective Loss of PARG Restores PARylation and Counteracts PARP Inhibitor-Mediated Synthetic Lethality. Cancer Cell 2018, 33, 1078-1093.e12. [CrossRef]

50. Sun, C.; Fang, Y.; Yin, J.; Chen, J.; Ju, Z.; Zhang, D.; Chen, X.; Vellano, C.P.; Jeong, K.J.; Ng, P.K.-S.; et al. Rational combination therapy with PARP and MEK inhibitors capitalizes on therapeutic liabilities in RAS mutant cancers. Sci. Transl. Med. 2017, 9, eaal5148. [CrossRef]

51. Tapodi, A.; Debreceni, B.; Hanto, K.; Bognar, Z.; Wittmann, I.; Gallyas, F.; Varbiro, G.; Sumegi, B. Pivotal Role of Akt Activation in Mitochondrial Protection and Cell Survival by Poly(ADP-ribose)polymerase-1 Inhibition in Oxidative Stress. J. Biol. Chem. 2005, 280, 35767-35775. [CrossRef]

52. Champiat, S.; Ileana, E.; Giaccone, G.; Besse, B.; Mountzios, G.; Eggermont, A.; Soria, J.-C. Incorporating Immune-Checkpoint Inhibitors into Systemic Therapy of NSCLC. J. Thorac. Oncol. 2014, 9, 144-153. [CrossRef] [PubMed]

53. Alme, A.K.B.; Karir, B.S.; Faltas, B.M.; Drake, C.G.; Kimmel, S.; Kimmel, S.; Cancer, C.; Medicine, W.C. Blocking immune checkpoints in prostate, kidney and urothelial cancer. Urol. Oncol. 2016, 34, 171-181. [CrossRef] [PubMed]

54. Corbo, C.; Cevenini, A.; Salvatore, F. Biomarker discovery by proteomics-based approaches for early detection and personalized medicine in colorectal cancer. Proteom. Clin. Appl. 2017, 11, 15-17. [CrossRef]

55. Kulasingam, V.; Diamandis, E.P. Strategies for discovering novel cancer biomarkers through utilization of emerging technologies. Nat. Clin. Pract. Oncol. 2008, 5, 588-599. [CrossRef] [PubMed]

56. Califf, R.M. Biomarker definitions and their applications. Exp. Biol. Med. 2018, 243, 213-221. [CrossRef] 
57. Paul, A.; Paul, S. The breast cancer susceptibility genes (BRCA) in breast and ovarian cancers. Front. Biosci. 2014, $19,605-618$. [CrossRef] [PubMed]

58. Crutchfield, C.A.; Thomas, S.N.; Sokoll, L.J.; Chan, D.W. Advances in mass spectrometry-based clinical biomarker discovery. Clin. Proteom. 2016, 13, 1-12. [CrossRef] [PubMed]

59. Hanahan, D.; Weinberg, R.A. Hallmarks of Cancer: The Next Generation. Cell 2011, 144, 646-674. [CrossRef] [PubMed]

60. Meyerson, M.; Gabriel, S.B.; Getz, G. Advances in understanding cancer genomes through second-generation sequencing. Nat. Rev. Genet. 2010, 11, 685-696. [CrossRef]

61. Hanash, S.M.; Baik, C.S.; Kallioniemi, O. Emerging molecular biomarkers-blood-based strategies to detect and monitor cancer. Nat. Rev. Clin. Oncol. 2011, 8, 142-150. [CrossRef]

62. Maitland, M.L.; Schilsky, R.L. Clinical trials in the era of personalized oncology. CA Cancer J. Clin. 2011, 61, 365-381. [CrossRef] [PubMed]

63. Simon, R. Critical Review of Umbrella, Basket, and Platform Designs for Oncology Clinical Trials. Clin. Pharmacol. Ther. 2017, 102, 934-941. [CrossRef] [PubMed]

64. Letai, A. Functional precision cancer medicine-moving beyond pure genomics. Nat. Med. 2017, 23, 1028-1035. [CrossRef] [PubMed]

65. West, H. No solid evidence, only hollow argument for universal tumor sequencing: Show me the data. JAMA Oncol. 2016, 2, 717-718. [CrossRef]

66. Prasad, V. Perspective: The precision-oncology illusion. Nature 2016, 537, S63. [CrossRef] [PubMed]

67. Hyman, D.M.; Taylor, B.S.; Baselga, J. Implementing Genome-Driven Oncology. Cell 2017, 168, 584-599. [CrossRef] [PubMed]

68. Zhang, B.; Whiteaker, J.R.; Hoofnagle, A.N.; Baird, G.S.; Rodland, K.D.; Paulovich, A.G. Clinical potential of mass spectrometrybased proteogenomics. Nat. Rev. Clin. Oncol. 2019, 16, 256-268. [CrossRef]

69. Goossens, N.; Nakagawa, S.; Sun, X.; Hoshida, Y. Cancer biomarker discovery and validation. Transl. Cancer Res. 2015, 4, 256-269.

70. Parkinson, D.R.; McCormack, R.T.; Keating, S.M.; Gutman, S.I.; Hamilton, S.R.; Mansfield, E.A.; Piper, M.A.; Deverka, P.; Frueh, F.W.; Jessup, J.M.; et al. Evidence of Clinical Utility: An Unmet Need in Molecular Diagnostics for Patients with Cancer. Clin. Cancer Res. 2014, 20, 1428-1444. [CrossRef]

71. Dobbin, K.K.; Cesano, A.; Alvarez, J.; Hawtin, R.; Janetzki, S.; Kirsch, I.; Masucci, G.V.; Robbins, P.B.; Selvan, S.R.; Streicher, H.Z.; et al. Validation of biomarkers to predict response to immunotherapy in cancer: Volume II—clinical validation and regulatory considerations. J. Immunother. Cancer 2016, 4, 77. [CrossRef]

72. Kraus, V.B. Biomarkers as drug development tools: Discovery, validation, qualification and use. Nat. Rev. Rheumatol. 2018, 14, 354-362. [CrossRef] [PubMed]

73. Bonifácio, V.D.B. Ovarian Cancer Biomarkers: Moving Forward in Early Detection. In Advances in Experimental Medicine and Biology; Metzler, J.B., Ed.; Springer Nature: Cham, Switzerland, 2020; Volume 1219, pp. 355-363.

74. Bast, R.C.; Feeney, M.; Lazarus, H.; Nadler, L.M.; Colvin, R.B.; Knapp, R.C. Reactivity of a monoclonal antibody with human ovarian carcinoma. J. Clin. Investig. 1981, 68, 1331-1337. [CrossRef] [PubMed]

75. Charkhchi, P.; Cybulski, C.; Gronwald, J.; Wong, F.O.; Narod, S.A.; Akbari, M.R. CA125 and Ovarian Cancer: A Comprehensive Review. Cancers 2020, 12, 3730. [CrossRef]

76. Ueland, F.R. A Perspective on Ovarian Cancer Biomarkers: Past, Present and Yet-To-Come. Diagnostics 2017, 7, 14. [CrossRef] [PubMed]

77. Arjmand, M.; Avval, F.Z. Clinical biomarkers for detection of ovarian cancer. J. Mol. Cancer 2019, 2, 3-7.

78. Moss, E.L.; Hollingworth, J.; Reynolds, T.M. The role of CA125 in clinical practice. J. Clin. Pathol. 2005, 58, 308-312. [CrossRef]

79. Boylan, K.L.M.; Geschwind, K.; Koopmeiners, J.S.; Geller, M.A.; Starr, T.K.; Skubitz, A.P.N. A multiplex platform for the identification of ovarian cancer biomarkers. Clin. Proteom. 2017, 14, 34. [CrossRef] [PubMed]

80. Klein, T.; Wang, W.; Yu, L.; Wu, K.; Boylan, K.L.; Vogel, R.I.; Skubitz, A.P.; Wang, J.-P. Development of a multiplexed giant magnetoresistive biosensor array prototype to quantify ovarian cancer biomarkers. Biosens. Bioelectron. 2019, 126, $301-307$. [CrossRef] [PubMed]

81. Boylan, K.L.M.; Afiuni-Zadeh, S.; Geller, M.A.; Argenta, P.A.; Griffin, T.J.; Skubitz, A.P.N. Evaluation of the potential of Pap test fluid and cervical swabs to serve as clinical diagnostic biospecimens for the detection of ovarian cancer by mass spectrometrybased proteomics. Clin. Proteom. 2021, 18, 1-12. [CrossRef] [PubMed]

82. Ueland, F.R.; DeSimone, C.P.; Seamon, L.G.; Miller, R.A.; Goodrich, S.; Podzielinski, I.; Sokoll, L.; Smith, A.; Van Nagell, J.R.; Zhang, Z. Effectiveness of a Multivariate Index Assay in the Preoperative Assessment of Ovarian Tumors. Obstet. Gynecol. 2011, 117, 1289-1297. [CrossRef]

83. Zhang, Z.; Chan, D.W. The Road from Discovery to Clinical Diagnostics: Lessons Learned from the First FDA-Cleared In Vitro Diagnostic Multivariate Index Assay of Proteomic Biomarkers. Cancer Epidemiol. Biomarkers Prev. 2010, 19, 2995-2999. [CrossRef] [PubMed]

84. Miller, R.W.; Smith, A.; DeSimone, C.P.; Seamon, L.; Goodrich, S.; Podzielinski, I.; Sokoll, L.; Van Nagell, J.R.; Zhang, Z.; Ueland, F.R. Performance of the American College of Obstetricians and Gynecologists' Ovarian Tumor Referral Guidelines With a Multivariate Index Assay. Obstet. Gynecol. 2011, 117, 1298-1306. [CrossRef]

85. Heliström, I.; Raycraft, J.; Hayden-Ledbetter, M.; Ledbetter, J.A.; Schummer, M.; McIntosh, M.; Drescher, C.; Urban, N.; Hellström, K.E. The HE4 (WFDC2) protein is a biomarker for ovarian carcinoma. Cancer Res. 2003, 63, 3695-3700. 
86. Moore, R.G.; Brown, A.K.; Miller, M.C.; Skates, S.; Allard, W.J.; Verch, T.; Steinhoff, M.; Messerlian, G.; DiSilvestro, P.; Granai, C.; et al. The use of multiple novel tumor biomarkers for the detection of ovarian carcinoma in patients with a pelvic mass. Gynecol. Oncol. 2008, 108, 402-408. [CrossRef]

87. Moore, R.G.; Miller, M.C.; DiSilvestro, P.; Landrum, L.M.; Gajewski, W.; Ball, J.J.; Skates, S.J. Evaluation of the Diagnostic Accuracy of the Risk of Ovarian Malignancy Algorithm in Women With a Pelvic Mass. Obstet. Gynecol. 2011, 118, 280-288. [CrossRef]

88. Moore, R.G.; Jabre-Raughley, M.; Brown, A.K.; Robison, K.M.; Miller, M.C.; Allard, W.J.; Kurman, R.J.; Bast, R.C.; Skates, S.J. Comparison of a novel multiple marker assay vs the Risk of Malignancy Index for the prediction of epithelial ovarian cancer in patients with a pelvic mass. Am. J. Obstet. Gynecol. 2010, 203, 228.e1-228.e6. [CrossRef] [PubMed]

89. Karlsen, M.A.; Sandhu, N.; Høgdall, C.; Christensen, I.J.; Nedergaard, L.; Lundvall, L.; Engelholm, S.A.; Pedersen, A.T.; Hartwell, D.; Lydolph, M.; et al. Evaluation of HE4, CA125, risk of ovarian malignancy algorithm (ROMA) and risk of malignancy index (RMI) as diagnostic tools of epithelial ovarian cancer in patients with a pelvic mass. Gynecol. Oncol. 2012, 127, 379-383. [CrossRef] [PubMed]

90. Bast, R.C.; Lu, Z.; Han, C.Y.; Lu, K.H.; Anderson, K.S.; Drescher, C.W.; Skates, S.J. Biomarkers and Strategies for Early Detection of Ovarian Cancer. Cancer Epidemiol. Biomarkers Prev. 2020, 29, 2504-2512. [CrossRef] [PubMed]

91. Coleman, R.L.; Herzog, T.J.; Chan, D.W.; Munroe, D.G.; Pappas, T.C.; Smith, A.; Zhang, Z.; Wolf, J. Validation of a secondgeneration multivariate index assay for malignancy risk of adnexal masses. Am. J. Obstet. Gynecol. 2016, 215, 82.e1-82.e11. [CrossRef] [PubMed]

92. Yang, W.-L.; Lu, Z.; Bast, R.C., Jr. The role of biomarkers in the management of epithelial ovarian cancer. Expert Rev. Mol. Diagn. 2017, 17, 577-591. [CrossRef]

93. Cramer, D.W.; Bast, R.C.; Berg, C.D.; Diamandis, E.P.; Godwin, A.K.; Hartge, P.; Lokshin, A.E.; Lu, K.H.; McIntosh, M.W.; Mor, G.; et al. Ovarian Cancer Biomarker Performance in Prostate, Lung, Colorectal, and Ovarian Cancer Screening Trial Specimens. Cancer Prev. Res. 2011, 4, 365-374. [CrossRef] [PubMed]

94. Savitski, M.M.; Reinhard, F.B.M.; Franken, H.; Werner, T.; Savitski, M.F.; Eberhard, D.; Molina, D.M.; Jafari, R.; Dovega, R.B.; Klaeger, S.; et al. Tracking cancer drugs in living cells by thermal profiling of the proteome. Science 2014, 346, 1255784. [CrossRef] [PubMed]

95. Mertins, P.; Cptac, N.; Mani, D.R.; Ruggles, K.V.; Gillette, M.A.; Clauser, K.R.; Wang, P.; Wang, X.; Qiao, J.W.; Cao, S.; et al. Proteogenomics connects somatic mutations to signalling in breast cancer. Nature 2016, 534, 55-62. [CrossRef]

96. Manes, N.P.; Angermann, B.R.; Koppenol-Raab, M.; An, E.; Sjoelund, V.H.; Sun, J.; Ishii, M.; Germain, R.N.; Meier-Schellersheim, M.; Nita-Lazar, A. Targeted Proteomics-Driven Computational Modeling of Macrophage S1P Chemosensing. Mol. Cell. Proteom. 2015, 14, 2661-2681. [CrossRef]

97. Swiatly, A.; Horala, A.; Matysiak, J.; Hajduk, J.; Nowak-Markwitz, E.; Kokot, Z.J. Understanding Ovarian Cancer: iTRAQ-Based Proteomics for Biomarker Discovery. Int. J. Mol. Sci. 2018, 19, 2240. [CrossRef] [PubMed]

98. Li, S.-L.; Ye, F.; Cai, W.-J.; Hu, H.-D.; Hu, P.; Ren, H.; Zhu, F.-F.; Zhang, D.-Z. Quantitative proteome analysis of multidrug resistance in human ovarian cancer cell line. J. Cell. Biochem. 2010, 109, 625-633. [CrossRef]

99. Zhang, H.; Liu, T.; Zhang, Z.; Payne, S.H.; Zhang, B.; McDermott, J.E.; Zhou, J.-Y.; Petyuk, V.A.; Chen, L.; Ray, D.; et al. Integrated Proteogenomic Characterization of Human High-Grade Serous Ovarian Cancer. Cell 2016, 166, 755-765. [CrossRef]

100. Aggarwal, K.; Choe, L.H.; Lee, K.H. Shotgun proteomics using the iTRAQ isobaric tags. Brief. Funct. Genom. Proteom. 2006, 5 , 112-120. [CrossRef]

101. Jiang, Z.; Zhang, C.; Gan, L.; Jia, Y.; Xiong, Y.; Chen, Y.; Wang, Z.; Wang, L.; Luo, H.; Li, J.; et al. iTRAQ-Based Quantitative Proteomics Approach Identifies Novel Diagnostic Biomarkers That Were Essential for Glutamine Metabolism and Redox Homeostasis for Gastric Cancer. Proteom. Clin. Appl. 2019, 13, e1800038. [CrossRef]

102. Xiao, K.; Yu, L.; Zhu, L.; Wu, Z.; Weng, X.; Qiu, G. Urine Proteomics Profiling and Functional Characterization of Knee Osteoarthritis Using iTRAQ Technology. Horm. Metab. Res. 2019, 51, 735-740. [CrossRef]

103. Zhang, L.; Elias, J.E. Relative Protein Quantification Using Tandem Mass Tag Mass Spectrometry. In Methods in Molecular Biology; Springer Nature: Cham, Switzerland, 2017; Volume 1550, pp. 185-198.

104. Liang, H.-C.; Lahert, E.; Pike, I.; Ward, M. Quantitation of protein post-translational modifications using isobaric tandem mass tags. Bioanalysis 2015, 7, 383-400. [CrossRef]

105. Huang, A.; Zhang, M.; Li, T.; Qin, X. Serum Proteomic Analysis by Tandem Mass Tags (TMT) Based Quantitative Proteomics in Gastric Cancer Patients. Clin. Lab. 2018, 64, 855-866. [CrossRef]

106. Ma, S.; Wang, C.; Zhao, B.; Ren, X.; Tian, S.; Wang, J.; Zhang, C.; Shao, Y.; Qiu, M.; Wang, X. Tandem mass tags labeled quantitative proteomics to study the effect of tobacco smoke exposure on the rat lung. Biochim. Biophys. Acta Proteins Proteom. 2018, 1866, 496-506. [CrossRef] [PubMed]

107. Ong, S.-E.; Blagoev, B.; Kratchmarova, I.; Kristensen, D.B.; Steen, H.; Pandey, A.; Mann, M. Stable Isotope Labeling by Amino Acids in Cell Culture, SILAC, as a Simple and Accurate Approach to Expression Proteomics. Mol. Cell. Proteom. 2002, 1, 376-386. [CrossRef] [PubMed]

108. Blagoev, B.; Kratchmarova, I.; Ong, S.-E.; Nielsen, M.; Foster, L.J.; Mann, M. A proteomics strategy to elucidate functional protein-protein interactions applied to EGF signaling. Nat. Biotechnol. 2003, 21, 315-318. [CrossRef] [PubMed]

109. Ong, S.-E.; Mann, M. A practical recipe for stable isotope labeling by amino acids in cell culture (SILAC). Nat. Protoc. 2006, 1 , 2650-2660. [CrossRef] [PubMed] 
110. Hoedt, E.; Zhang, G.; Neubert, T.A. Stable Isotope Labeling by Amino Acids in Cell Culture (SILAC) for Quantitative Proteomics. Adv. Exp. Med. Biol. 2019, 1140, 531-539. [CrossRef]

111. Li, K.W.; Gonzalez-Lozano, M.A.; Koopmans, F.; Smit, A.B. Recent Developments in Data Independent Acquisition (DIA) Mass Spectrometry: Application of Quantitative Analysis of the Brain Proteome. Front. Mol. Neurosci. 2020, 13, 564446. [CrossRef]

112. Meier, F.; Geyer, P.E.; Winter, S.V.; Cox, J.; Mann, M. BoxCar acquisition method enables single-shot proteomics at a depth of 10,000 proteins in 100 minutes. Nat. Methods 2018, 15, 440-448. [CrossRef] [PubMed]

113. Haverland, N.A.; Fox, H.S.; Ciborowski, P. Quantitative Proteomics by SWATH-MS Reveals Altered Expression of Nucleic Acid Binding and Regulatory Proteins in HIV-1-Infected Macrophages. J. Proteome Res. 2014, 13, 2109-2119. [CrossRef]

114. Liu, Y.; Chen, J.; Sethi, A.; Li, Q.K.; Chen, L.; Collins, B.; Gillet, L.C.J.; Wollscheid, B.; Zhang, H.; Aebersold, R. Glycoproteomic Analysis of Prostate Cancer Tissues by SWATH Mass Spectrometry Discovers N-acylethanolamine Acid Amidase and Protein Tyrosine Kinase 7 as Signatures for Tumor Aggressiveness. Mol. Cell. Proteom. 2014, 13, 1753-1768. [CrossRef]

115. Meier, F.; Brunner, A.-D.; Frank, M.; Ha, A.; Bludau, I.; Voytik, E.; Kaspar-Schoenefeld, S.; Lubeck, M.; Raether, O.; Bache, N.; et al. diaPASEF: Parallel accumulation-serial fragmentation combined with data-independent acquisition. Nat. Methods 2020, 17, 1229-1236. [CrossRef]

116. Distler, U.; Kuharev, J.; Navarro, P.; Tenzer, S. Label-free quantification in ion mobility-enhanced data-independent acquisition proteomics. Nat. Protoc. 2016, 11, 795-812. [CrossRef]

117. Huang, L.; Wickramasekara, S.I.; Akinyeke, T.; Stewart, B.S.; Jiang, Y.; Raber, J.; Maier, C.S. Ion mobility-enhanced MSE-based label-free analysis reveals effects of low-dose radiation post contextual fear conditioning training on the mouse hippocampal proteome. J. Proteom. 2016, 140, 24-36. [CrossRef]

118. Moseley, M.A.; Hughes, C.J.; Juvvadi, P.R.; Soderblom, E.J.; Lennon, S.; Perkins, S.R.; Thompson, J.W.; Steinbach, W.J.; Geromanos, S.J.; Wildgoose, J.; et al. Scanning Quadrupole Data-Independent Acquisition, Part A: Qualitative and Quantitative Characterization. J. Proteome Res. 2018, 17, 770-779. [CrossRef] [PubMed]

119. Gillet, L.C.; Leitner, A.; Aebersold, R. Mass Spectrometry Applied to Bottom-Up Proteomics: Entering the High-Throughput Era for Hypothesis Testing. Annu. Rev. Anal. Chem. 2016, 9, 449-472. [CrossRef] [PubMed]

120. Thomas, S.N.; Zhang, H. Targeted proteomic assays for the verification of global proteomics insights. Expert Rev. Proteom. 2016, 13, 897-899. [CrossRef] [PubMed]

121. Uzozie, A.C.; Aebersold, R. Advancing translational research and precision medicine with targeted proteomics. J. Proteom. 2018, 189, 1-10. [CrossRef]

122. Shi, T.; Song, E.; Nie, S.; Rodland, K.D.; Liu, T.; Qian, W.-J.; Smith, R.D. Advances in targeted proteomics and applications to biomedical research. Proteomics 2016, 16, 2160-2182. [CrossRef] [PubMed]

123. Gillet, L.C.; Navarro, P.; Tate, S.; Röst, H.; Selevsek, N.; Reiter, L.; Bonner, R.; Aebersold, R. Targeted Data Extraction of the MS/MS Spectra Generated by Data-independent Acquisition: A New Concept for Consistent and Accurate Proteome Analysis. Mol. Cell. Proteom. 2012, 11. [CrossRef]

124. Addona, T.A.; Abbatiello, S.E.; Schilling, B.; Skates, S.J.; Mani, D.R.; Bunk, D.M.; Spiegelman, C.H.; Zimmerman, L.J.; Ham, A.-J.L.; Keshishian, H.; et al. Multi-site assessment of the precision and reproducibility of multiple reaction monitoring-based measurements of proteins in plasma. Nat. Biotechnol. 2009, 27, 633-641. [CrossRef]

125. Thomas, S.N.; Harlan, R.; Chen, J.; Aiyetan, P.; Liu, Y.; Sokoll, L.J.; Aebersold, R.; Chan, D.W.; Zhang, H. Multiplexed Targeted Mass Spectrometry-Based Assays for the Quantification of N-Linked Glycosite-Containing Peptides in Serum. Anal. Chem. 2015, 87, 10830-10838. [CrossRef] [PubMed]

126. Lange, V.; Picotti, P.; Domon, B.; Aebersold, R. Selected reaction monitoring for quantitative proteomics: A tutorial. Mol. Syst. Biol. 2008, 4, 222. [CrossRef]

127. Shi, T.; Su, D.; Liu, T.; Tang, K.; Camp, D.G.; Qian, W.-J.; Smith, R.D. Advancing the sensitivity of selected reaction monitoringbased targeted quantitative proteomics. Proteomics 2012, 12, 1074-1092. [CrossRef] [PubMed]

128. Peterson, A.C.; Russell, J.D.; Bailey, D.J.; Westphall, M.S.; Coon, J.J. Parallel Reaction Monitoring for High Resolution and High Mass Accuracy Quantitative, Targeted Proteomics. Mol. Cell. Proteom. 2012, 11, 1475-1488. [CrossRef]

129. Rauniyar, N. Parallel Reaction Monitoring: A Targeted Experiment Performed Using High Resolution and High Mass Accuracy Mass Spectrometry. Int. J. Mol. Sci. 2015, 16, 28566-28581. [CrossRef]

130. Liebler, D.C.; Zimmerman, L.J. Targeted Quantitation of Proteins by Mass Spectrometry. Biochemistry 2013, 52, 3797-3806. [CrossRef] [PubMed]

131. Gillette, M.A.; Carr, S.A. Quantitative analysis of peptides and proteins in biomedicine by targeted mass spectrometry. Nat. Methods 2013, 10, 28-34. [CrossRef]

132. Schubert, O.T.; Röst, H.L.; Collins, B.C.; Rosenberger, G.; Aebersold, R. Quantitative proteomics: Challenges and opportunities in basic and applied research. Nat. Protoc. 2017, 12, 1289-1294. [CrossRef]

133. Zheng, Y.; Zhang, C.; Croucher, D.R.; Soliman, M.A.; St-Denis, N.; Pasculescu, A.; Taylor, L.; Tate, S.A.; Hardy, W.R.; Colwill, K.; et al. Temporal regulation of EGF signalling networks by the scaffold protein Shc1. Nature 2013, 499, 166-171. [CrossRef]

134. Altvater, M.; Chang, Y.; Melnik, A.; Occhipinti, L.; Schütz, S.; Rothenbusch, U.; Picotti, P.; Panse, V.G. Targeted proteomics reveals compositional dynamics of 60 S pre-ribosomes after nuclear export. Mol. Syst. Biol. 2012, 8, 628. [CrossRef] 
135. De Graaf, E.L.; Kaplon, J.; Mohammed, S.; Vereijken, L.A.M.; Duarte, D.P.; Gallego, L.R.; Heck, A.J.R.; Peeper, D.S.; Altelaar, A.F.M. Signal Transduction Reaction Monitoring Deciphers Site-Specific PI3K-mTOR/MAPK Pathway Dynamics in Oncogene-Induced Senescence. J. Proteome Res. 2015, 14, 2906-2914. [CrossRef]

136. Gallien, S.; Domon, B. Advances in high-resolution quantitative proteomics: Implications for clinical applications. Expert Rev. Proteom. 2015, 12, 489-498. [CrossRef]

137. Liu, Y.; Hüttenhain, R.; Collins, B.; Aebersold, R. Mass spectrometric protein maps for biomarker discovery and clinical research. Expert Rev. Mol. Diagn. 2013, 13, 811-825. [CrossRef] [PubMed]

138. Picotti, P.; Aebersold, R. Selected reaction monitoring-based proteomics: Workflows, potential, pitfalls and future directions. Nat. Methods 2012, 9, 555-566. [CrossRef] [PubMed]

139. Kim, J.W.; Nie, B.; Sahm, H.; Brown, D.P.G.; Tegeler, T.; You, J.-S.; Wang, M. Targeted quantitative analysis of superoxide dismutase 1 in cisplatin-sensitive and cisplatin-resistant human ovarian cancer cells. J. Chromatogr. B 2010, 878, 700-704. [CrossRef] [PubMed]

140. Wang, Q.; Zhang, M.; Tomita, T.; Vogelstein, J.T.; Zhou, S.; Papadopoulos, N.; Kinzler, K.W.; Vogelstein, B. Selected reaction monitoring approach for validating peptide biomarkers. Proc. Natl. Acad. Sci. USA 2017, 114, 13519-13524. [CrossRef]

141. Hüttenhain, R.; Choi, M.; de la Fuente, L.M.; Oehl, K.; Chang, C.-Y.; Zimmermann, A.-K.; Malander, S.; Olsson, H.; Surinova, S.; Clough, T.; et al. A Targeted Mass Spectrometry Strategy for Developing Proteomic Biomarkers: A Case Study of Epithelial Ovarian Cancer. Mol. Cell. Proteom. 2019, 18, 1836-1850. [CrossRef] [PubMed]

142. Tang, H.-Y.; Beer, L.A.; Tanyi, J.L.; Zhang, R.; Liu, Q.; Speicher, D.W. Protein isoform-specific validation defines multiple chloride intracellular channel and tropomyosin isoforms as serological biomarkers of ovarian cancer. J. Proteom. 2013, 89, 165-178. [CrossRef]

143. Shi, T.; Gao, Y.; Quek, S.I.; Fillmore, T.L.; Nicora, C.D.; Su, D.; Zhao, R.; Kagan, J.; Srivastava, S.; Rodland, K.D.; et al. A Highly Sensitive Targeted Mass Spectrometric Assay for Quantification of AGR2 Protein in Human Urine and Serum. J. Proteome Res. 2014, 13, 875-882. [CrossRef]

144. He, J.; Sun, X.; Shi, T.; Schepmoes, A.A.; Fillmore, T.L.; Petyuk, V.A.; Xie, F.; Zhao, R.; Gritsenko, M.A.; Yang, F.; et al. Antibodyindependent targeted quantification of TMPRSS2-ERG fusion protein products in prostate cancer. Mol. Oncol. 2014, 8, 1169-1180. [CrossRef] [PubMed]

145. Kim, Y.J.; Sertamo, K.; Pierrard, M.-A.; Mesmin, C.; Kim, S.Y.; Schlesser, M.; Berchem, G.; Domon, B. Verification of the Biomarker Candidates for Non-small-cell Lung Cancer Using a Targeted Proteomics Approach. J. Proteome Res. 2015, 14, 1412-1419. [CrossRef]

146. Kim, Y.J.; Gallien, S.; El-Khoury, V.; Goswami, P.; Sertamo, K.; Schlesser, M.; Berchem, G.; Domon, B. Quantification of SAA1 and SAA2 in lung cancer plasma using the isotype-specific PRM assays. Proteomics 2015, 15, 3116-3125. [CrossRef] [PubMed]

147. Kume, H.; Muraoka, S.; Kuga, T.; Adachi, J.; Narumi, R.; Watanabe, S.; Kuwano, M.; Kodera, Y.; Matsushita, K.; Fukuoka, J.; et al. Discovery of Colorectal Cancer Biomarker Candidates by Membrane Proteomic Analysis and Subsequent Verification using Selected Reaction Monitoring (SRM) and Tissue Microarray (TMA) Analysis. Mol. Cell. Proteom. 2014, 13, 1471-1484. [CrossRef] [PubMed]

148. Cohen, A.; Wang, E.; Chisholm, K.A.; Kostyleva, R.; O'Connor-McCourt, M.; Pinto, D.M. A mass spectrometry-based plasma protein panel targeting the tumor microenvironment in patients with breast cancer. J. Proteom. 2013, 81, 135-147. [CrossRef] [PubMed]

149. Kim, H.; Kim, K.; Yu, S.J.; Jang, E.S.; Yu, J.; Cho, G.; Yoon, J.-H.; Kim, Y. Development of Biomarkers for Screening Hepatocellular Carcinoma Using Global Data Mining and Multiple Reaction Monitoring. PLoS ONE 2013, 8, e63468. [CrossRef] [PubMed]

150. Lee, J.Y.; Kim, J.Y.; Park, G.W.; Cheon, M.H.; Kwon, K.-H.; Ahn, Y.H.; Moon, M.H.; Lee, H.; Paik, Y.K.; Yoo, J.S. Targeted Mass Spectrometric Approach for Biomarker Discovery and Validation with Nonglycosylated Tryptic Peptides from N-linked Glycoproteins in Human Plasma. Mol. Cell. Proteom. 2011, 10. [CrossRef]

151. Zhao, Y.; Jia, W.; Sun, W.; Jin, W.; Guo, L.; Wei, J.; Ying, W.; Zhang, Y.; Xie, Y.; Jiang, Y.; et al. Combination of Improved 18O Incorporation and Multiple Reaction Monitoring: A Universal Strategy for Absolute Quantitative Verification of Serum Candidate Biomarkers of Liver Cancer. J. Proteome Res. 2010, 9, 3319-3327. [CrossRef] [PubMed]

152. Ahn, Y.H.; Shin, P.M.; Oh, N.R.; Park, G.W.; Kim, H.; Yoo, J.S. A lectin-coupled, targeted proteomic mass spectrometry (MRM MS) platform for identification of multiple liver cancer biomarkers in human plasma. J. Proteom. 2012, 75, 5507-5515. [CrossRef]

153. Pan, S.; Chen, R.; Brand, R.E.; Hawley, S.; Tamura, Y.; Gafken, P.R.; Milless, B.P.; Goodlett, D.R.; Rush, J.; Brentnall, T.A. Multiplex Targeted Proteomic Assay for Biomarker Detection in Plasma: A Pancreatic Cancer Biomarker Case Study. J. Proteome Res. 2012, 11, 1937-1948. [CrossRef]

154. Yoneyama, T.; Ohtsuki, S.; Ono, M.; Ohmine, K.; Uchida, Y.; Yamada, T.; Tachikawa, M.; Terasaki, T. Quantitative Targeted Absolute Proteomics-Based Large-Scale Quantification of Proline-Hydroxylated $\alpha$-Fibrinogen in Plasma for Pancreatic Cancer Diagnosis. J. Proteome Res. 2013, 12, 753-762. [CrossRef] [PubMed] 